\title{
Stratigraphic and Paleoenvironmental Reconstruction of a Mid-Pliocene Fossil Site in the High Arctic (Ellesmere Island, Nunavut): Evidence of an Ancient Peatland with Beaver Activity
}

\author{
William Travis Mitchell, ${ }^{1}$ Natalia Rybczynski, ${ }^{2,3}$ Claudia Schröder-Adams, ${ }^{1}$ Paul B. Hamilton, ${ }^{4}$ \\ Robin Smith ${ }^{2}$ and Marianne Douglas ${ }^{5}$
}

(Received 12 June 2015; accepted in revised form 27 January 2016)

\begin{abstract}
Neogene terrestrial deposits of sand and gravel with preserved wood and peat accumulations occur in many areas of the High Arctic. The Pliocene-aged Beaver Pond fossil site (Ellesmere Island, NU) is one such site that differs from other sites in the great thickness of its peat layer and the presence of a rich vertebrate faunal assemblage, along with numerous beaver-cut sticks. Although the site has been the subject of intense paleontological investigations for over two decades, there has not been a reconstruction of its depositional history. In this study, measured sections within and surrounding the site established the stratigraphy and lateral continuity of the stratigraphic units. Grain size analysis, loss on ignition, and fossil diatom assemblages were examined to reconstruct paleoenvironmental changes in the sequence. The base of the section was interpreted as a floodplain system. Using modern peat accumulation rates, the maximum thickness $(240 \mathrm{~cm})$ of the overlying peat layer is estimated to represent $49000 \pm 12000$ years. From this evidence, we suggest that during the peat formation interval, beaver activity may have played a role in creating an open water environment. The peat unit was overlain by sand, rich in organic matter and charcoal, suggesting environmental change and fire occurrence.
\end{abstract}

Key words: sedimentology; diatom; paleoenvironmental reconstruction; Ellesmere Island; Beaver Pond Site; Pliocene; beaver; peat; fossil; fire

RÉSUMÉ. En maints endroits de l'Extrême-Arctique, on trouve des dépôts continentaux néogènes de sable et de gravier accompagnés d'accumulations préservées de bois et de tourbe. Le site fossilifère Beaver Pond datant du Pliocène (île d'Ellesmere, Nunavut) est l'un de ces sites qui diffèrent d'autres sites en ce qui a trait à la grande épaisseur de sa couche de tourbe, à la présence d'un riche assemblage de faune vertébrée et aux nombreuses branches de bois coupées par les castors. Bien que ce site ait fait l'objet de fouilles paléontologiques intenses pendant plus de deux décennies, aucune reconstruction de son passé sédimentaire n'a été effectuée. Dans cette étude, diverses sections mesurées à l'intérieur et aux alentours du site ont permis d'établir la stratigraphie et la continuité latérale des unités stratigraphiques. L'analyse de la taille du grain, la perte par calcination et les assemblages de diatomées fossiles ont été examinés dans le but de reconstruire les changements paléoenvironnementaux de la séquence. La base de la section a été interprétée comme un système de plaine inondable. À l'aide des taux d'accumulation moderne de tourbe, on estime que l'épaisseur maximale $(240 \mathrm{~cm})$ de la couche de tourbe supérieure représente $49000 \pm 12000$ ans. À partir de cette évidence, nous suggérons que pendant l'intervalle de la formation de tourbe, l'activité des castors aurait pu jouer un rôle dans la création d'un environnement d'eau libre. L'unité de tourbe était recouverte de sable, riche en matière organique et en charbon, ce qui suggère un changement environnemental et l'occurrence de feux.

Mots clés : sédimentologie; diatomée; reconstruction paléoenvironnementale; île d'Ellesmere; site Beaver Pond; Pliocène; castor; tourbe; fossile; feu

Traduit pour la revue Arctic par Nicole Giguère.

\section{INTRODUCTION}

The geologic record of the Canadian High Arctic shows that in the past this region supported forest ecosystems vastly different from the polar tundra landscapes that characterize the High Arctic today (e.g., Harington, 2001). Fossil forest remains are known from Mesozoic to early and late Cenozoic deposits across the Arctic (Francis, 1988; Greenwood and Basinger, 1993; Fyles et al., 1994; Matthews and Fyles, 2000; Falcon-Lang et al., 2004). Most of the

\footnotetext{
${ }^{1}$ Carleton University, Department of Earth Sciences, 1125 Colonel By Drive, Ottawa, Ontario K1S 5B6, Canada

${ }^{2}$ Canadian Museum of Nature, Palaeobiology, PO Box 3443 Station D, Ottawa, Ontario K1P 6P4, Canada

${ }^{3}$ Corresponding author: nrybczynski@mus-nature.ca

${ }^{4}$ Canadian Museum of Nature, Botany, PO Box 3443 Station D, Ottawa, Ontario K1P 6P4, Canada

${ }^{5}$ Queen's University, Department of Biology, Kingston, Ontario K7L 3N6, Canada

(C) The Arctic Institute of North America
} 
known late Neogene sites were discovered by John Fyles (Geological Survey of Canada) through a series of surveys across the Canadian Arctic Archipelago (CAA) that began in the 1960s and continued into the early 1990s. The deposits are characterized by unconsolidated sand and gravel, along with plant and invertebrate remains that are exquisitely preserved, being essentially mummified (Matthews and Fyles, 2000). The thickest Pliocene deposits are referred to as the Beaufort Formation and are formed by an extensive braided river system. These deposits are represented today by a northwesterly thickening unit that extends in a belt, $1200 \mathrm{~km}$ along the western margin of the CAA (Fyles, 1990). Exposures of the Beaufort Formation are known to be up to $60 \mathrm{~m}$ thick and include mummified wood and peat (Fyles, 1990; Davies et al., 2014). Reflection seismic data (Prince Patrick Island) and exploration well data (Meighen Island) indicate the thickness of the Beaufort Formation (onshore) to be from several hundred meters to one kilometer (Fyles, 1990). In the eastern CAA, small exposures of potentially time-equivalent deposits are known as the "high-terrace" deposits. One such site, hereafter referred to as "the Beaver Pond site" $\left(78^{\circ} 33^{\prime} \mathrm{N}, 82^{\circ} 22^{\prime} \mathrm{W}\right)$, is a small exposure lying within a collection of high-terrace deposits up to $40 \mathrm{~m}$ thick and spanning an area roughly $1 \mathrm{~km}^{2}$ near Strathcona Fiord on west-central Ellesmere Island, Nunavut, Canada (Fig. 1) (Matthews and Fyles, 2000). The collection of Pliocene-aged sites, referred to in the literature as the "Beaver Peat," was discovered in 1961 and preserves evidence of a boreal-type forest and wetland environment (Hulbert and Harington, 1999; Elias and Matthews, 2002; Hutchison and Harington, 2002; Tedford and Harington, 2003; Ballantyne et al., 2006, 2010; Murray et al., 2009; Csank et al., 2011a, b). The Beaver Peat was originally considered to represent a single peat layer with extensive slumping that resulted in peat "layers" outcropping at different elevations (Matthews and Ovenden, 1990). However, the work presented here provides a different interpretation, namely that slumping was not as extensive as previously considered; there are at least two laterally continuous peat layers preserved within the unit, separated vertically by tens of meters. The following overview of the previously interpreted paleoecology is based on samples from different localities within the "Beaver Peat," some of which may represent slightly different ages.

The plant macrofossil remains recovered from the "Beaver Peat" sites included 56 vascular plants (Matthews and Fyles, 2000). The tree assemblage was dominated by the extinct larch (Larix groenlandii) and also included birch (Betula spp., both a dwarf shrub and arboreal types), willow (Salix sp.), alder (Alnus cf. alnobetula), pine (Pinus cf. strobus, P. pumila), spruce (Picea marianalrubra complex) and cedar (Thuja occidentalis). The vascular plant assemblage was otherwise dominated by wetland species, in particular bulrush (Scirpus sp.), Scheuchzaria grasses, horsetail (Carex diandra), and buckbean (Menyanthes sp.) (Matthews and Ovenden, 1990). There were 30 bryophyte species identified with the most abundant being Scorpidium scorpioides, a taxon characteristic of mineral-rich

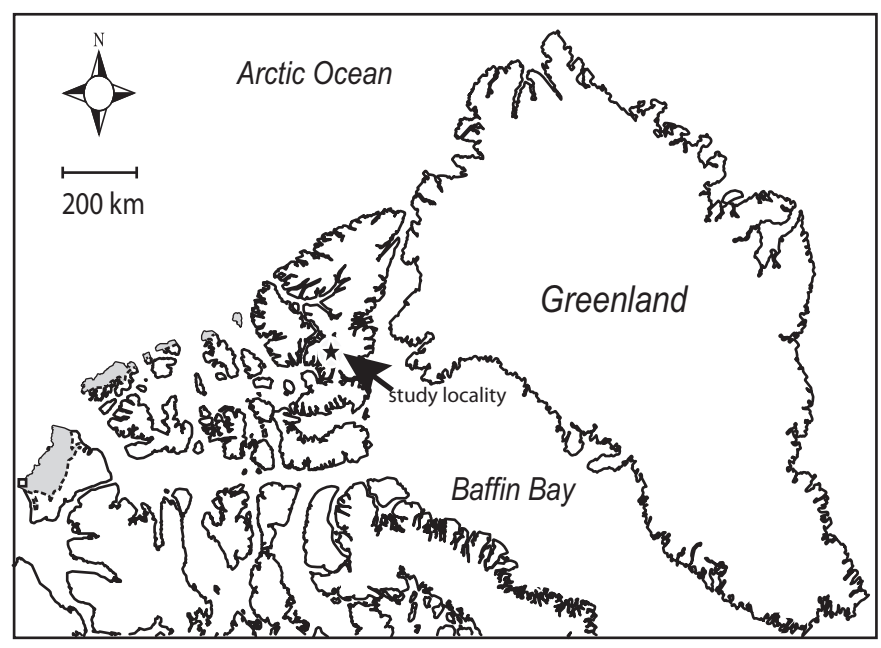

FIG. 1. Map showing the location of the Beaver Pond fossil site on Ellesmere Island, Nunavut. The star marks the location of the fossil site $\left(78^{\circ} 33^{\prime} \mathrm{N}\right.$, $82^{\circ} 22^{\prime} \mathrm{W}$ ). Grey shaded areas show the location of the Beaufort Formation.

fens (Matthews and Ovenden, 1990; Matthews and Fyles, 2000). Nearly a hundred arthropod fossil taxa, a bryozoan, and a freshwater sponge have been identified (Matthews and Fyles, 2000), as well as at least five species of freshwater molluscs, including Gyraulus albus (Harington, 2001). The multiproxy paleoenvironmental evidence from the peat samples suggests a northern, mineral-rich wetland and floodplain environment surrounded by forest. The presence of certain tundra-specific beetles also suggests that a tundra environment persisted within the collection of "Beaver Peat" sites (Matthews and Fyles, 2000).

The Beaver Pond fossil site is within the Beaver Peat collection of sites. The former is significant, in part, because it is the only known Pliocene-aged site north of $55^{\circ} \mathrm{N}$ to yield a significant assemblage of vertebrate fossils. This includes a rich Neogene mammal assemblage with lineages derived from both North America and Eurasia. Prior to the opening of the Bering Strait, which is estimated to have first occurred at the end of the Miocene at 5.32 Ma (Gladenkov et al., 2002), the Northern Hemisphere continents would have been linked via Beringia. This isthmus allowed the northern reaches of Eurasia and North America to exist as a continuous northern biotic province. The vertebrate community at the Beaver Pond site contains a mix of Eurasian and North American lineages. Eurasian taxa include the extinct badger, Arctomeles sotnikovae (Tedford and Harington, 2003), an arvicoline rodent (Zakrzewski and Harington, 2001), and a percid fish (Murray et al., 2009). Taxa that most likely originated in North America include a rabbit relative (Hypolagus sp.), the beaver (Dipoides sp.), and the black bear-like "Ursus" abstrusus (Dawson and Harington, 2007). However, there is also evidence of Arctic endemism, as seen in the dental remains of a peculiar small deer relative (Boreameryx) (Dawson and Harington, 2007) and the shrew Arctisorex polaris (Hutchison and Harington, 2002). The Beaver Pond site is so named because of the abundance of fossil remains of the small beaver (Dipoides 
sp.) and the presence of well-preserved beaver-cut sticks, showing cut marks characteristic of branch harvesting activity (Rybczynski, 2008). Other sites that preserve beaver-cut sticks include a small exposure across the fiord from the Beaver Pond site referred to as the Taggart site $\left(\sim 78^{\circ} 34^{\prime} \mathrm{N} ; 82^{\circ} 4^{\prime} \mathrm{W}\right)$. For the Beaver Pond site, Tedford and Harington (2003) speculated that a $75 \mathrm{~cm}$ long accumulation of mud, entwined beaver-cut sticks, and cobbles, found embedded within the peat, constituted the displaced core of a beaver-made dam. Further, C.R. Harington (pers. comm. 2015) interprets the presence of a small accumulation of seven or eight beaver-cut sticks, found at a similar level as the remnant core of a beaver dam, as a feeding pile. The sticks in the "feeding pile" were embedded in compact organic rich silt, and were closer to vertical in their orientation, in contrast with those in the "dam," which were closer to horizontal. This evidence of construction behavior (i.e., possible feeding pile and dam) found in association with a partially articulated Dipoides skeleton at roughly the same level, is considered indicative of beavers living within dammed waters, in a manner similar to the modern Castor.

Fossil evidence places the Beaver Pond fossil site within the Pliocene Epoch (5.3-2.6 Ma). For example, the site contains Paliurus-type seeds (Rhamnaceae, Buckthorn family), considered typical of High Arctic Pliocene deposits (Matthews and Ovenden, 1990). Also, multiple mammal taxa from the Beaver Pond site (e.g., horse and badger) compare well with a Late Neogene mammal assemblage from the Yushe Basin of northeastern China (Tedford and Harington, 2003), dated using magnetostratigraphy to 5.5-4.5 Ma (Tedford et al., 1991). The fossil bear species from the Beaver Pond site ("Ursus" abstrusus) is otherwise known only from Blancan sites in mid-latitudes of North America, including the Hagerman fossil beds (Idaho), where it is associated with an age of 3.9-3.6 Ma (Tedford and Harington, 2003; Ruez, 2009). Given that the Idaho and Yushe sites are geographically (and paleo-ecologically) remote from the Beaver Pond site (both are more than $4000 \mathrm{~km}$ away), we favor dating of the sediments from the deposit itself. Recent terrestrial cosmogenic nuclide dates from the Beaver Pond site and Fyles Leaf Bed site, suggest a slightly younger age of approximately $3.5 \mathrm{Ma}$ (Rybczynski et al., 2013).

During the mid-Pliocene, the continental configuration and atmospheric $\mathrm{CO}_{2}$ levels were similar to those of today (Tripati et al., 2009; Pagani et al., 2010). Consequently, the Mid Pliocene has been considered to be a historical analogue for current warming, providing an example of climate system dynamics for planet Earth with atmospheric $\mathrm{CO}_{2}$ of $\sim 400$ ppm (Dowsett et al., 2012). Climate estimates from the Beaver Pond site and the nearby Fyles Leaf Bed site, using multiple proxies, show evidence of a climate Mean Annual Temperature (MAT) that was $14^{\circ}$ to $22^{\circ} \mathrm{C}$ warmer than today (Table 1). The Beaver Pond site and other sites, including the recently described Lake El'gygytgyn record (NE Arctic Russia) (Brigham-Grette et al., 2013), offer key evidence for understanding the history of the Arctic terrestrial climate in the context of global warming. Despite the importance of the Beaver Pond site in paleoecological and paleoclimate research, the sedimentology and depositional history of the site have not been characterized. This study provides a stratigraphic and sedimentological description of the Beaver Pond site deposit and nearby deposits within the Beaver Peat collection of sites. Here we estimate the duration of the thick peat layer that characterizes the Beaver Pond site, provide a description of the sparse diatom assemblage, and consider the possible role of beaver activity in the creation of the site. The depositional history described here provides a much-needed context for ongoing paleontological and paleoenvironmental studies at the peat-rich fossil sites of Strathcona Fiord.

\section{GEOLOGICAL SETTING}

The Beaufort Formation is a widespread, easily recognized stratigraphic unit in the High Arctic, comprising mainly a thick layer of Neogene-aged sand and gravel. The deposits have been interpreted as braided river deposits and contain fossilized plant material, particularly moss and wood (Fyles, 1990). The Beaufort Formation extends along the western margin of the CAA from Banks Island northward to Meighen Island (Fig. 1), and as originally defined, excludes possible time-equivalent "high-terrace" deposits on Ellesmere Island and elsewhere (Fyles, 1990; Fyles et al., 1994). It is beyond the scope of this manuscript to determine whether the Beaufort Formation should be redefined to include the latter sediments. On Meighen Island, the deposits have been dated using biostratigraphy and $\mathrm{Sr}$ isotope analysis of extinct mollusk shells (Arctica sp.) to approximately $3 \mathrm{Ma}$ (Matthews and Ovenden, 1990; Matthews and Telka, 1997). The Beaver Pond site is situated in "high-terrace" sediments near the head of Strathcona Fiord at an elevation of $380 \mathrm{~m}$ above sea level and overlies the Eureka Sound Group (Fig. 2). The regional stratigraphy described above is based on Marincovich and Zinsmeister (1991), who examined Tertiary marine mollusks found in the Eureka Sound Group at Strathcona Fiord.

The Beaver Pond site represents a roughly $40 \mathrm{~m}$ sequence of sand and gravel, capped by glacial till. This study focuses on the portion of the section that includes the thickest peat layers. No evidence was found of a depositional hiatus within the peat-forming units (Tedford and Harington, 2003). Before fossil excavation in 1992, the peat was $240 \mathrm{~cm}$ thick, but fossil retrieval reduced its thickness on site to approximately $100 \mathrm{~cm}$ (Fig. 3A, B). Matthews and Ovenden (1990) suggested that the site may be slumped; however, field observations from this study contradict that interpretation (see Results).

\section{METHODS}

Fieldwork was conducted at the Beaver Pond site and surrounding areas during the summers of 1993, 2008, and 


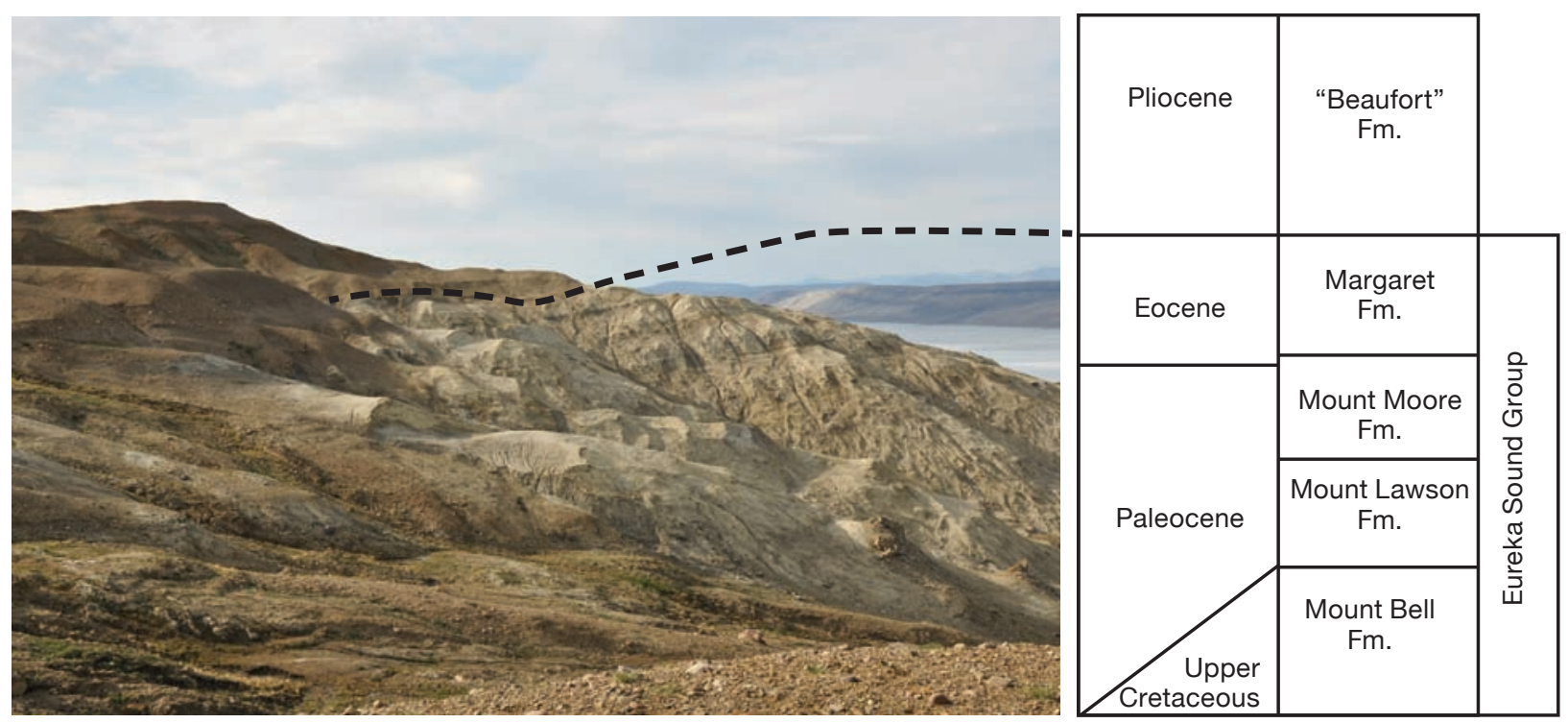

FIG. 2. At Strathcona Fiord, an unconformity, represented by the black line, separates the Pliocene-aged "high terrace" alluvium (equivalent to the Beaufort Formation) from the Mount Moore Formation of the Eureka Sound Group. The Margaret Formation is not present at the Beaver Pond locality (stratigraphy adapted from Marincovich and Zinsmeister, 1991).

2010. The primary stratigraphic reconstruction was based on the collections from 2010, while supporting sampling of selected sections was from the 1993 collections. Six exposed stratigraphic sections, designated as sections A through $\mathrm{F}$, were measured in order to determine the lateral continuity of peat beds and whether the site of interest represents a slumped deposit (Fig. 4). Sections A through $\mathrm{D}$ related to the Beaver Pond fossil site and corresponded with the original excavation area (excavated mostly in the 1990s), whereas E and F were outside that area. Vertical extents of exposed sections varied from 80 to $400+\mathrm{cm}$, and section locations were selected to display variability of spatial characteristics of the site. Sections A through D were located within a $10 \mathrm{~m}$ lateral interval and represented the main sampling area. Sections E and F were located approximately $40-50 \mathrm{~m}$ southwest and northeast, respectively, of the main sampling area (Fig. 4). In total, 80 sediment samples were collected at intervals ranging from 2 to $60 \mathrm{~cm}$ in order to sample vertical changes in lithologies and to document facies changes. We counted the beaver-cut and non-beaver-cut sticks found throughout the sampling area. Different peat types were characterized in the field on the basis of vegetative composition.

The 80 field samples, representing sections A through F, were partitioned to create three sets of replicated samples. Subsamples for grain size analysis and diatom examination were prepared together and treated to remove all organic material and carbonates. The third subsample set was used for loss on ignition tests.

Eighty sedimentological subsamples were treated by acid digestion and then subjected to grain size analysis with a Beckman-Coulter LS 230 laser diffraction particle size analyzer (which analyzes grains $\leq 2 \mathrm{~mm}$ ). Grain size mean, mode, sorting, skewness, and kurtosis were calculated using the Fraunhofer optical model (Etzler and Deanne, 1997).
Loss on ignition (LOI) is an efficient way to determine the organic matter and carbonate content of a sediment sample. Eighty subsamples were dried at $110^{\circ} \mathrm{C}$ for 24 hours and then heated at $550^{\circ} \mathrm{C}$ for four hours and at $950^{\circ} \mathrm{C}$ for two hours. We then calculated the amount of organic and carbonate material in the sample using equations outlined by Heiri et al. (2001). We used the following equation to determine organic content:

$$
\text { LOI }_{550}=100 *\left(\left(\text { Dry weight }_{110}-\text { Dry weight }_{550}\right) / \text { Dry weight }_{110}\right)
$$

and this second equation to determine the carbonate content:

$$
\text { LOI }_{950}=100 *\left(\left(\text { Dry weight }_{550}-\text { Dry weight }_{950}\right) / \text { Dry weight }_{110}\right)
$$

Two additional sample series collected by C.R. Harington in 1993 were analyzed for siliceous microfossils. The two sample series were from the thickest peat (the "classic section," Fig. 3A) excavated in the 1990s. The CR-93-10 series represents a $200 \mathrm{~cm}$ thick section of peat, sampled at $20 \mathrm{~cm}$ intervals from the south side of the in situ peat block (this is the side visible in Fig. 3A). The presence of a sand unit that appears continuously through the exposure indicates that the bottom of the CR-93-10 series correlates with the $52 \mathrm{~cm}$ mark of Section A (Fig. 4). The CR-93-59 series (70 $\mathrm{cm}$ thick) was sampled from the back of the section (north side) and from the top of the section, at $10 \mathrm{~cm}$ intervals. The stratigraphically highest samples for both CR-9310 and CR-93-59 were considered to represent the same level. The top of the peat unit was exposed, so it is likely that a small thickness was lost through erosion. Nevertheless, it is clear that the top samples for both series would have been close to the top of the peat unit. 

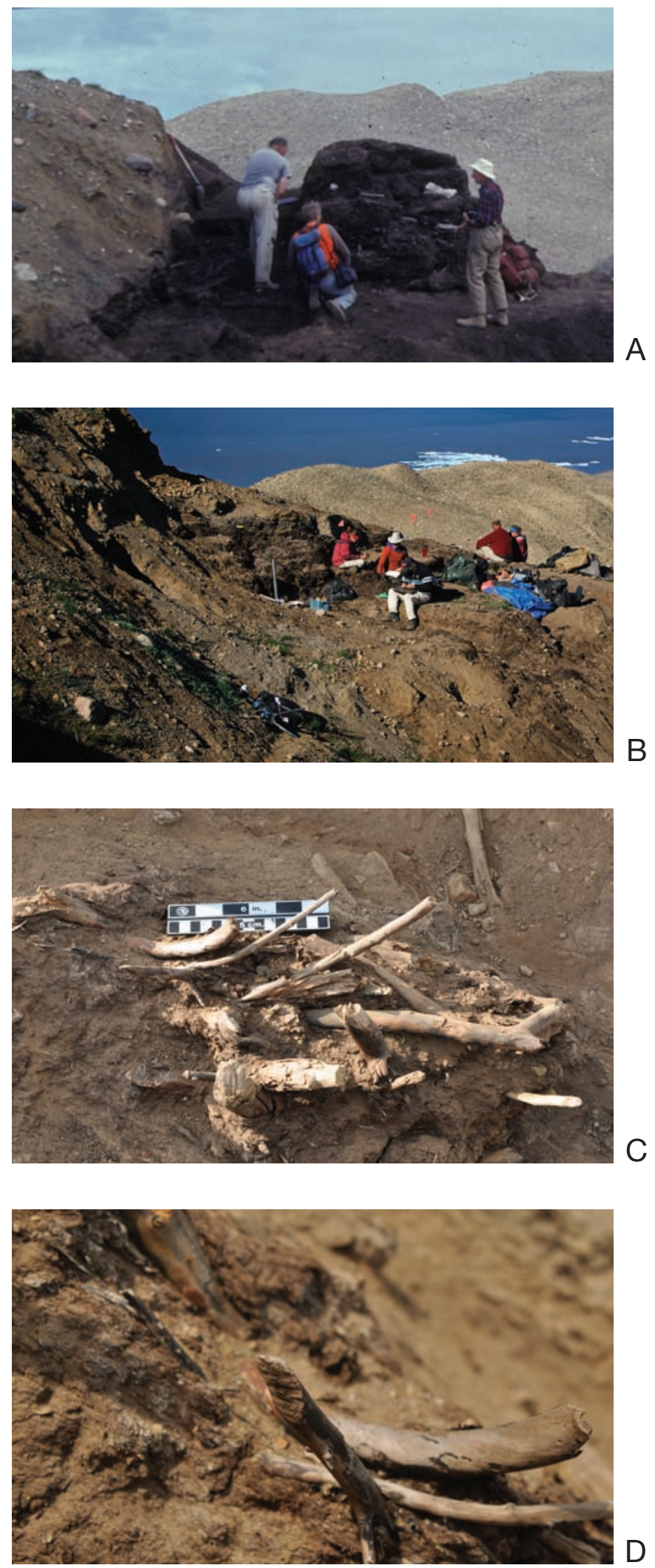

FIG. 3. A) The Beaver Pond site before major excavations began. The blocklike dark unit is peat that is $240 \mathrm{~cm}$ thick (Photo: Kennedy/CMN). B) The Beaver Pond site in 2008. Notice the peat block has been excavated (Photo: M. Lipman). C) Accumulation of sticks, many beaver-cut, near the top of the peat unit (Unit III). D) Close-up of accumulation of sticks, shown in C. Note beaver-cut stick in centre of frame.
Diatom samples from two sources were observed. During the 1993 field season, sediment samples (CR-93-10 and CR-93-59) were collected from the "classic section" at the Beaver Pond site (Fig. 3A). The diatoms found in these samples were identified, but not published. All other diatoms discussed here were identified from samples collected during the 2010 field season and prepared as described below. Diatom subsamples were prepared by acid digestion (Gajewski et al., 1997) and examined with a Leica DM 2500 light microscope $(1000 \times)$. The diatom samples and slides are housed at the Canadian Museum of Nature in the Canadian National Collection for Algae catalogued as CANA $85062-850142,85159-85164$, and $85167-85170$. The samples were examined for siliceous microfossils, including diatoms, testate amoebae (Rhizopoda), and chrysophyte cysts. However, only the diatoms and testate amoeba are reported. Chrysophyte cysts are difficult to associate with extant or extinct species and therefore of limited use in the paleoenvironmental reconstruction for this study. Several genera of testate amoeba (Rhizopoda) use internally formed siliceous plates that are glued together to form their testae. These plates are morphologically distinct to genus level and can be used to reconstruct past assemblages. Treatment of samples by oxidation of organic materials (nitric and sulphuric acids 1:1) left behind siliceous microfossils, which were then mounted in Naphrax and examined using light microscopy. The testate amoebae were identified according to Douglas and Smol (2002).

\section{Peatland Duration}

Peatland duration refers to the length of time required to accumulate a given thickness of peat. The Pliocene age of the deposits prevents the use of carbon dating to determine peatland duration. Therefore, we used published peat growth rates from modern peatland sites. The peatland type is inferred from the moss species present in the Beaver Pond peat accumulations. Specifically, the dominance of the brown moss Scorpidium scorpioides, and species such as Calliergon richardsonii, Campylium stellatum, Ditrichum flexicaule, Paludella squarrossa, and Tomenthypnum nitens (Miller, 1980; Matthews and Ovenden, 1990; Matthews and Fyles, 2000) suggests that the main period of peat accumulation represents a mineral-rich fen environment. Fens are peatlands that receive water supply from groundwater rich in dissolved minerals, often from association with calcareous rocks, with vegetation dominated by graminoids, sedges, and brown mosses (Mitsch et al., 2009; Keddy, 2010). We estimated the duration of the peat layer at the Beaver Pond site using published, timeweighted carbon accumulation averages from five Holocene analogue forest fen sites (Alaska, $\mathrm{n}=3$; and Finland, $\mathrm{n}=2$ ) (Mäkilä et al., 2001; Mäkilä and Moisanen, 2007; Yu et al., 2009). These fens are all more than 10000 years old and were selected because they are similar to the Beaver Pond fossil site, in that they are currently located near the tree line, but not within the zone of continuous permafrost, and 


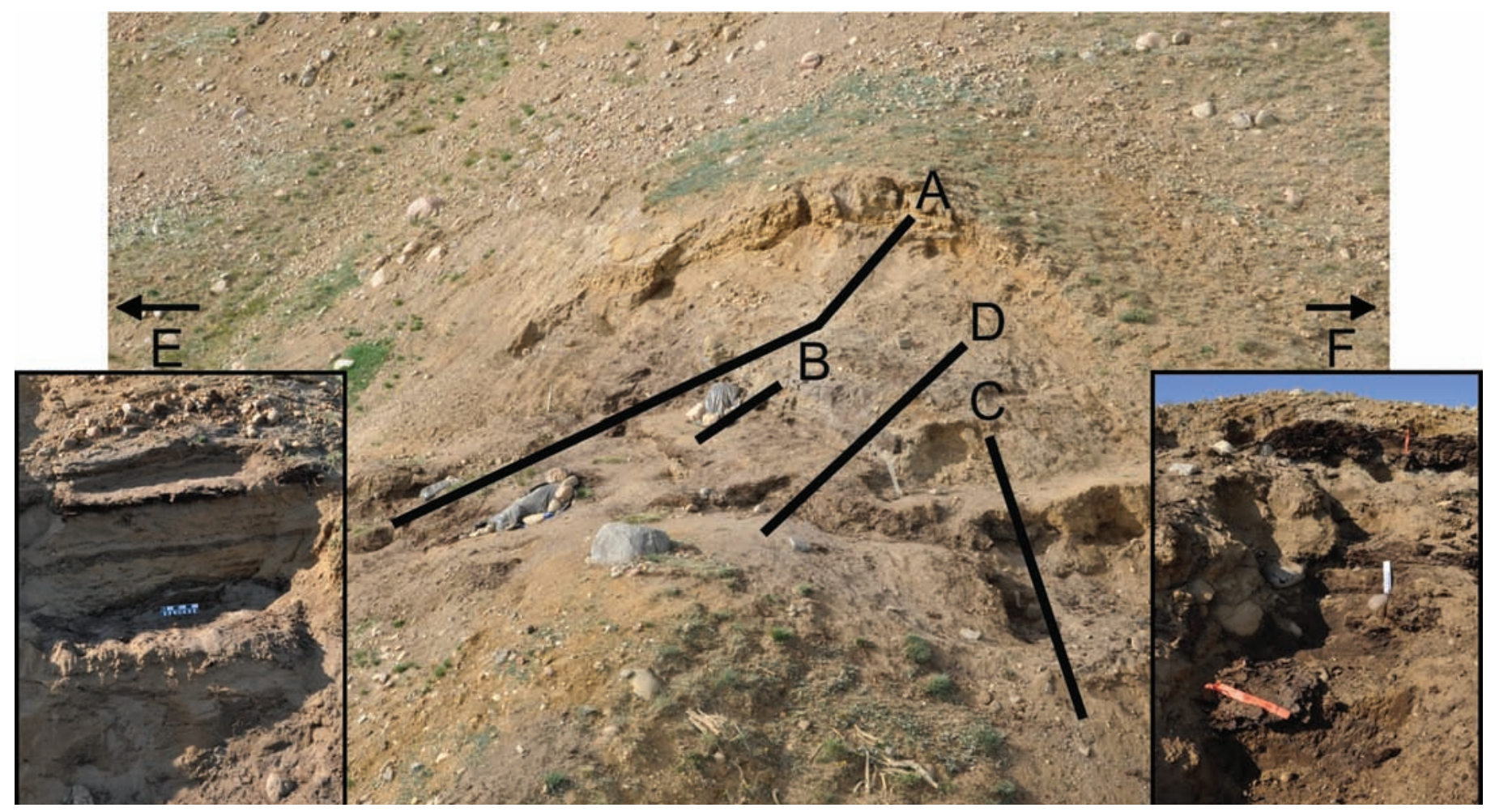

FIG. 4. Locations of stratigraphic sections recorded at the Beaver Pond site during the summer of 2010. The distance between Section A and Section C is approximately $10 \mathrm{~m}$. Sections A through D represent the main study area and sections E and F were sampled to examine the lateral consistency of the beds.

are associated with mean annual temperatures of $-2^{\circ}$ to $2^{\circ} \mathrm{C}$ (Table 2).

In order to estimate peatland duration, we determined the density of the carbon in the fossil peat. Four hand samples from the main peat unit (Unit III) were weighed and their surface structure was recorded using an Arius 3D laser scanner, (currently at Carleton University). For each sample, we calculated the volume from the surface area, using Pointstream 3DImageSuite (Arius3D, 2007), and the carbon content using LOI (see above) and assuming that carbon content is $50 \%$ of the mass $(\mathrm{g})$ of peat dry mass (Roulet et al., 2007).

The duration of the Beaver Pond site peat layer (D) in years was estimated by multiplying the density of carbon in the fossil peat $\left(\mathrm{C}_{\mathrm{f}}\right)$ by the thickness of the fossil peat $(\mathrm{T})$ and dividing by the average grams of carbon per $\mathrm{cm}^{2}$ per year (rate, R) observed in modern peatlands (Table 2), so that:

$$
\mathrm{D}=\left(\mathrm{C}_{\mathrm{f}} * \mathrm{~T}\right) / \mathrm{R}
$$

The maximum fossil peat thickness in the measured section was $100 \mathrm{~cm}$, whereas at the original location of peat excavation years before, only a couple of meters away, the peat was up to $240 \mathrm{~cm}$ thick (Fig. 3A). Peat duration was calculated for both the $100 \mathrm{~cm}$ and $240 \mathrm{~cm}$ thick peat. Given that the variation in the rate of Holocene peat growth (see Table 2) was much greater than the measurement variation, the error was calculated by dividing the standard deviation of the results by the average of the results.

\section{RESULTS}

The general lithology of the Beaver Pond site was composed of quartz-rich sand. The peat units were variable stratigraphically and laterally, however, lateral continuity of key beds suggested the originally excavated area was in situ (contra Matthews and Ovenden, 1990). Lithostratigraphic correlation criteria are discussed with each unit. Sections $\mathrm{E}, \mathrm{A}, \mathrm{C}$, and $\mathrm{F}$ were long sections, whereas sections $\mathrm{B}$ and $\mathrm{D}$ were short and therefore did not expose the lower units (Fig. 5). The exposed stratigraphic interval at the Beaver Pond site was defined in six units, all of which were present in Section A (Figs. 5, 6). The units designated as I to VI were characterized by differences in general lithology (i.e., sand-dominated vs. peat-dominated), sedimentology, and loss on ignition characteristics (Fig. 7).

\section{Detailed Unit Description}

The following lithological description of the vertical facies changes is based on Section A. Although correlation lines were drawn to neighboring, less extensive sections, significant facies variability and thickness changes were observed (Fig. 5). The primary component of Unit I was medium grained (1.5-2 $\phi)$, subangular to subrounded, poorly sorted, quartz-rich sand and subangular to subrounded 5-25 cm thick cobbles. Several $5-20 \mathrm{~cm}$ peat lenses were interspersed within this interval. No sedimentary structures were observed. The organic content was low $(<5 \%)$, and carbonate content was generally around 
TABLE 1. Temperature reconstructions for the Beaver Pond fossil site.

\begin{tabular}{|c|c|c|c|}
\hline Temperature estimate $\left({ }^{\circ} \mathrm{C}\right)$ & Warmer than present $\left({ }^{\circ} \mathrm{C}\right)^{1}$ & Method & Reference \\
\hline \multicolumn{4}{|l|}{ Mean annual temperature: } \\
\hline$-5.5 \pm 1.9$ & +14.2 & Tree ring width and $\delta^{18} \mathrm{O}$ isotopes & Ballantyne et al., 2006 \\
\hline$-0.4 \pm 0.4$ & $+19 \pm 0.4$ & $\begin{array}{l}\text { Composite estimate from tetraether, } \\
\text { tree ring width and } \delta^{18} \mathrm{O} \text { isotopes and } \\
\text { paleovegetation community composition }\end{array}$ & Ballantyne et al., 2010 \\
\hline$-1.4 \pm 4.0$ & $+18.3 \pm 4.1$ & Tree ring width and $\delta^{18} \mathrm{O}$ isotopes & Csank et al., 2011a \\
\hline \multicolumn{4}{|l|}{ Growing season temperature: } \\
\hline - & $10-15^{2}$ & Beetle community composition & Elias and Matthews, 2002 \\
\hline$-1.6 \pm 1.3^{3}$ & $+\sim 11-16$ & $\begin{array}{l}\delta^{18} \mathrm{O} \text { of peat and mollusk shell; } \\
\text { 'clumped isotope' thermometry of } \\
\text { mollusc shell }\end{array}$ & Csank et al., 2011b \\
\hline $15.8 \pm 5.0^{4}$ & $+11.8 \pm 5.1$ & Tree ring width and $\delta^{18} \mathrm{O}$ isotopes & Csank et al., 2011a \\
\hline
\end{tabular}

${ }^{1}$ Compared with Eureka weather station data, 1971-2000, at Eureka, Nunavut $\left(79^{\circ} \mathrm{N}, 85^{\circ} \mathrm{W}\right)$, with a mean annual temperature of $-19.7^{\circ} \mathrm{C}$ (Environment Canada, 2015).

${ }^{2}$ Mean temperatures of the warmest month.

${ }^{3}$ May-September temperature.

${ }^{4}$ June-July temperature.

TABLE 2. Characteristics of five Holocene fen sites used to estimate the peatland duration at the Beaver Pond fossil site. The fen sites are near the northern tree line, but outside the continuous permafrost zone. Modified from Yu et al. (2009).

\begin{tabular}{|c|c|c|c|c|c|c|}
\hline Site no. & Region & Location & $\begin{array}{c}\text { Modern } \\
\operatorname{MAT}\left({ }^{\circ} \mathrm{C}\right)^{1}\end{array}$ & $\begin{array}{l}\text { Basal age } \\
\text { of fen (KA) }\end{array}$ & $\begin{array}{l}\text { Time-weighted } \\
\text { carbon addition rate } \\
\text { (g Carbon } / \mathrm{m}^{2} / \text { year) }\end{array}$ & $\begin{array}{l}\text { Reference for } \\
\text { carbon addition rate }\end{array}$ \\
\hline 1 & Alaska & $60^{\circ} 27^{\prime} \mathrm{N} ; 151^{\circ} 14^{\prime} \mathrm{W}$ & 1.9 & 11.4 & 13.1 & Yu et al., 2009 \\
\hline 2 & Alaska & $60^{\circ} 38^{\prime} \mathrm{N} ; 151^{\circ} 04^{\prime} \mathrm{W}$ & 1.9 & 11.5 & 12.3 & Yu et al., 2009 \\
\hline 3 & Alaska & $60^{\circ} 25^{\prime} \mathrm{N} ; 150^{\circ} 54^{\prime} \mathrm{W}$ & 1.9 & 13.6 & 10.7 & Yu et al., 2009 \\
\hline 4 & Finland & $68^{\circ} 24^{\prime} \mathrm{N} ; 23^{\circ} 33^{\prime} \mathrm{E}$ & -2 to 1 & 9.8 & 13.7 & Mäkilä and Moisanen, 2007 \\
\hline 5 & Finland & $65^{\circ} 39^{\prime} \mathrm{N} ; 27^{\circ} 19^{\prime} \mathrm{E}$ & -2 to 1 & 9.6 & 22.4 & Mäkilä et al., 2001 \\
\hline
\end{tabular}

${ }^{1}$ MAT $=$ Mean annual temperature. MATs for Alaskan sites are from the Kenai weather station (Yu et al., 2009), while those for Forest Lapland aapa mire regions are from Mäkilä and Moisanen (2007).

4\% (Fig. 7). Discontinuous peat lenses observed in Unit I appear to have been ripped up elsewhere and then transported and therefore are considered not in situ. The main component of the peat lenses was moss, deposited in thin sheets to form moss mats with light density and a golden to reddish-brown colour. There was little coarse fibrous material or other plant debris except thin, strap-like vegetative remains of a pondweed (cf. Potamogeton sp.). Unit I was present in sections $\mathrm{E}, \mathrm{A}, \mathrm{C}$, and $\mathrm{F}$ and was characterized by medium sand with a few cobbles and ripped-up peat lenses (Fig. 5).

Unit II was composed of three beds: a $2 \mathrm{~cm}$ thick organic rich sediment layer at the base; a $10 \mathrm{~cm}$ thick peat layer, the lowermost peat observed in any section; and a $10 \mathrm{~cm}$ thick sand layer with subangular to subrounded cobbles and no sedimentary structures. The sorting varied from moderate, associated with the smallest grain size, to poor. The peat in this unit corresponded to a sharp decline of grain size from medium-to-fine to very fine sand $(2-4 \phi)$ and had the highest organic content in any section $(40 \%-61 \%)$. The carbonate was generally around $4 \%$. The peat layer found in Section A was also composed primarily of moss. However, rather than being deposited in mats of compressed thin sheets in discontinuous lenses, the peat formed in patchy layers and exhibited a fibrous and springy texture, with many defoliated moss stems. Unit II was present in all four long sections and was marked by a change from medium sand to a persistent peat bed overlain by medium-grained sand (Fig. 5).

Unit III, the main peat accumulation measured in Section A, consisted of a $100 \mathrm{~cm}$ (maximum thickness) peat layer that tapers in thickness toward the northeast end of the exposure (Fig. 5). The peat layer is continuous across sections $\mathrm{A}, \mathrm{B}, \mathrm{C}$, and $\mathrm{D}$. The peripheral section $\mathrm{E}$ had a thin peat bed, and section $F$ had a thick but stratigraphically higher peat, suggesting a restricted and spatially variable area of significant peat accumulation. The peat contained a substantial amount of quartz-dominated sand. The sections that represented Unit III displayed a wide range of grain sizes $(0.5-3.5 \phi)$. Variability within the peat unit was observed where organic rich sand separated peat layers (Fig. 7). The sorting was generally poor except at $167 \mathrm{~cm}$ of Section A, where sorting was moderate. The increased sorting was associated with a decrease in grain size $(3.2 \phi)$. The organic content of the peat was high $(17 \%-38 \%)$, but lower than in Unit II. In areas with organic-rich sand, the organic 


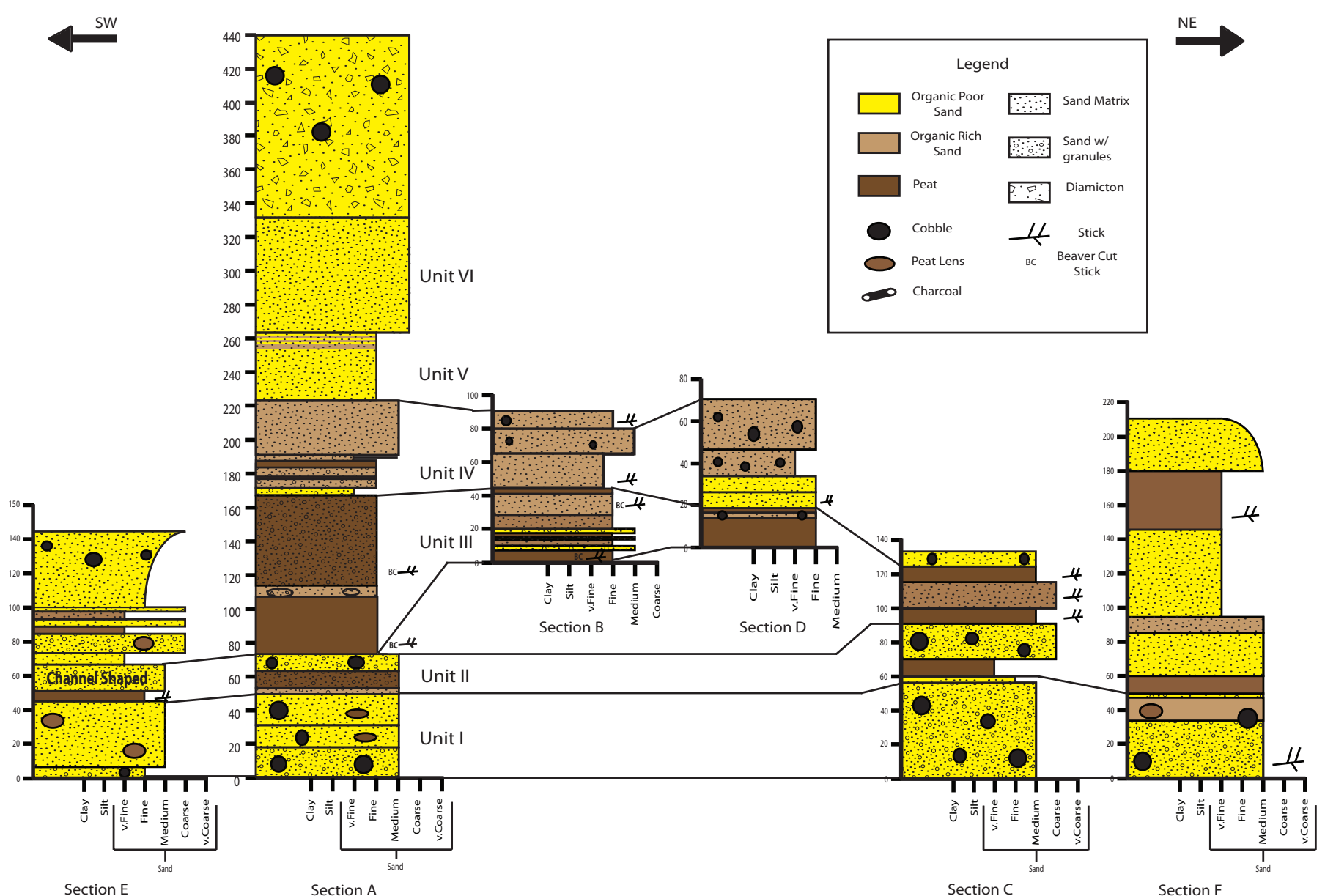

FIG. 5. Sections A through F from the Beaver Pond fossil site, showing proposed stratigraphic correlation between sections. Height is measured in centimeters.

content was as low as $5 \%$. The carbonate in this unit was especially low $(1.2 \%-1.7 \%)$.

The peat sampled from the base of Unit III in the different sections varied in texture and composition. In Section A, peat was composed primarily of moss and pondweed (cf. Potamogeton) along with some narrow, flattened stems of an unidentified plant; however, evidence of deciduous vegetation in the form of birch (Betula) leaves (dwarf variety, cf. Betula nana) were also present. Moving laterally to Section B, below the main beaver-cut stick accumulation (Fig. 3C), the peat material also included evidence of aquatic to semi-aquatic plants such as buckbean (Menyanthes), horsetail (Equisetum), and pondweed (cf. Potamogeton), as well as patchy accumulations of twigs and sticks. In Section C, terrestrial components such as Betula leaves, as well as ericaceous leaves of species such as the shrub Vaccinium, were much more abundant. These components indicated that Section C was likely closer to the wetland shoreline than Section A.

A stick count resulted in a total of 30 beaver-cut sticks (Fig. 3C, D) and 107 uncut sticks (ends broken). The highest concentration of beaver-cut sticks was observed in Section B (Figs. 5, 8). The accumulation of beaver-cut sticks was only partially exposed. Most of the sticks appeared to be oriented from NW to SE, with some larger sticks perpendicular to that line (Fig. 3C, D). Most of the sticks, both beaver cut and uncut, occurred in the thickest peat unit (Unit III). Note that many sticks were removed in previous excavations, and current counts refer to the remaining in situ sticks found at the Beaver Pond site (Fig. 3A). No beaver-cut sticks were found in Sections E or F. The peat at the level of the main beaver-cut stick accumulation in Section B was composed of a dense, muddy matrix. In this matrix, sparse moss was observed, along with terrestrial plant matter such as Betula leaves, larger twigs (diameter $5 \mathrm{~mm}$ or more), and Larix cones and needles. The observed plant matter suggested input from shoreline vegetation that included deciduous angiosperm and coniferous trees.

Unit IV was a complex unit that represented a significant change in the depositional environment marked by the loss of thick peat accumulation. Unit IV was correlated in sections $\mathrm{A}, \mathrm{B}$, and $\mathrm{D}$ to a characteristic lithological change. A thin, fine to very fine sand $(2.7-3.7 \phi)$ formed the base and transitioned upward into an organic-rich sand layer, which contained many small, aligned twigs with pieces of charcoal and other organic materials (Fig. 6: inset). The sorting was generally poor except at $174 \mathrm{~cm}$ in Section A, where the sediment was well sorted and associated with the finest grain size. Small rounded pebbles and cobbles were also present (Fig. 6). This unit weathered to a grey colour, something not 


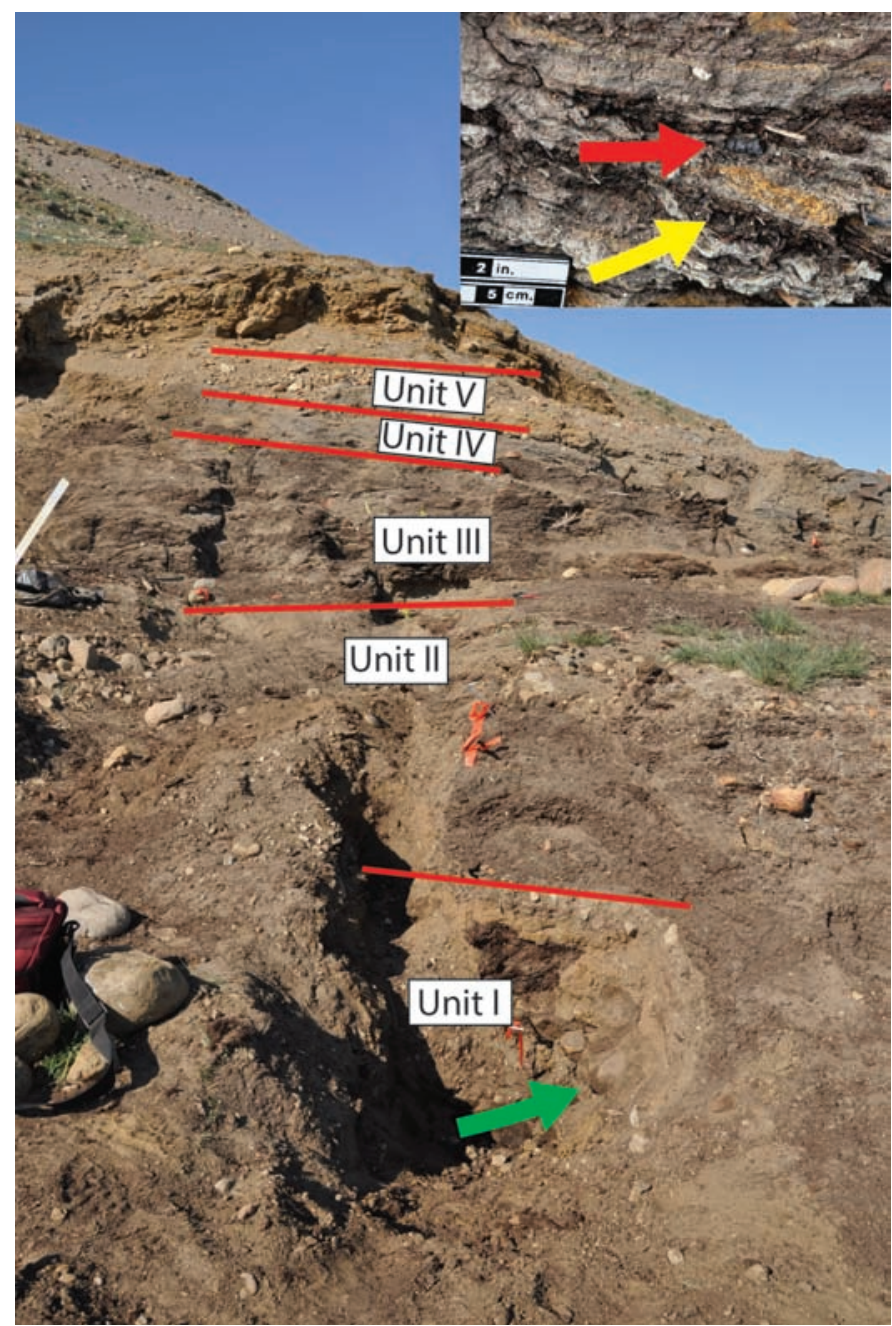

FIG. 6. Sedimentological units I through V found at the Beaver Pond site. Note the cobbles indicated by the green arrow. The inset of Unit 4 shows the alignment of twigs and charcoal (red arrow).

observed anywhere else in the section. The organic content ranged from $10 \%$ to $18 \%$, and the carbonate varied from $1.0 \%$ to $1.9 \%$. Higher carbonate contents occurred at $75 \mathrm{~cm}$ of Section B (3.5\%) and $37 \mathrm{~cm}$ of Section D (6.9\%) and were associated with low organic contents. Carbonates might be responsible for the light grey colour of this unit.

Units $\mathrm{V}$ and VI were measured only in section A (Figs. 5, 6). Unit $\mathrm{V}$ consisted of a mixture of organic rich and pure yellow quartz sand, whereas Unit VI consisted of pure quartz-rich yellow sand. There were no visible sedimentary structures in either unit. The sands in both units were medium grained and poorly sorted. Unit $\mathrm{V}$ was slightly more organic rich than Unit VI $(1.4 \%-3.9 \%$ vs. $1.2 \%-1.6 \%$ ) and slightly more carbonate rich. Unit VI was overlain by coarse grained sediment of unknown age and possibly of slumped origin (Figs. 5, 6).

\section{Peatland Duration}

The peat thickness $(100 \mathrm{~cm})$ within the measured section at the Beaver Pond site (Unit III) was estimated
TABLE 3. Estimated peat duration at the Beaver Pond fossil site for $100 \mathrm{~cm}$ and $240 \mathrm{~cm}$ peat thicknesses, based on rates of carbon accumulation from modern/Holocene analogue sites (see Table 2). The error for the analogue site calculations is estimated from the square root of the measurement errors. The error for the average is the standard error.

\begin{tabular}{lcc}
\hline \hline & \multicolumn{2}{c}{ Duration for fossil peat thickness } \\
\cline { 2 - 3 } Analogue Site no. & $100 \mathrm{~cm}\left(\times 10^{3}\right.$ years $)$ & $240 \mathrm{~cm}\left(\times 10^{3}\right.$ years $)$ \\
\hline 1 & $21 \pm 3$ & $51 \pm 7$ \\
2 & $23 \pm 3$ & $54 \pm 8$ \\
3 & $26 \pm 4$ & $62 \pm 9$ \\
4 & $20 \pm 3$ & $49 \pm 7$ \\
5 & $12 \pm 2$ & $30 \pm 4$ \\
Average & $20 \pm 5$ & $49 \pm 11$ \\
\hline \hline
\end{tabular}

to have accumulated over $20449 \pm 4999$ years (Table 3, Fig. 5). However, the thickness of the original peat section $(240 \mathrm{~cm})$ was estimated to represent $49077 \pm 11997$ years of peat growth (Fig. 3A). The large error in the age estimation is the result of a calculation based on the growth rate of modern fens, which is highly variable.

\section{Diatoms}

The diatom assemblage recovered from the Beaver Pond site represented mainly extant freshwater taxa. In total, 473 intact diatoms valves were observed plus numerous fragmented valves from the 1993 and 2010 samples (Fig. 9A, B). The greatest number of diatoms $(n=136)$ was recovered from $100 \mathrm{~cm}$, which represents the base in the CR-9310 series, and the second richest sample was collected at $80 \mathrm{~cm}(\mathrm{n}=55)$. Diatoms from the 2010 collections were much rarer, representing only $9 \%$ of the total diatoms observed (Fig. 9A). Differences in abundance between the 1993 and 2010 sections likely relate to the location of peat accumulation within the beaver pond.

Taxa from 19 genera were observed with $95 \%$ recovered from the peats of Section A (Unit III, 73-168 cm) (Figs. 5, $9 \mathrm{~A}, \mathrm{~B})$. The most dominant taxa (largest number of occurrences) were Staurosira venter sensu lato, Staurosirella pinnata, Pseudostaurosirella brevistriata, Eunotia spp. (including E. incisa and E. glacialis), Cocconeis sp., and Pinnularia borealis.

In the 2010 samples, the basal $70 \mathrm{~cm}$ of Unit III in Section A contained predominantly small araphid "Staurosiroid" species. Pinnularia borealis was present in the lowermost portion of the section, along with some Eunotia taxa. The greatest concentration of diatoms in this interval $(0-74 \mathrm{~cm})$ correlates with the onset of peat formation at the Beaver Pond site $(52 \mathrm{~cm})$. Diatom counts increased within the thickest peat accumulation $(74-168 \mathrm{~cm})$. The centric diatom Puncticulata bodanica was rare and occurred between 92 and $147 \mathrm{~cm}$. At $132 \mathrm{~cm}$, species richness increased as Eunotia taxa reappeared. In the interval $168-184 \mathrm{~cm}$, Tetracyclus sp. and Eunotia spp. were the only taxa recovered. Ellerbreckia arenaria f. teres was 

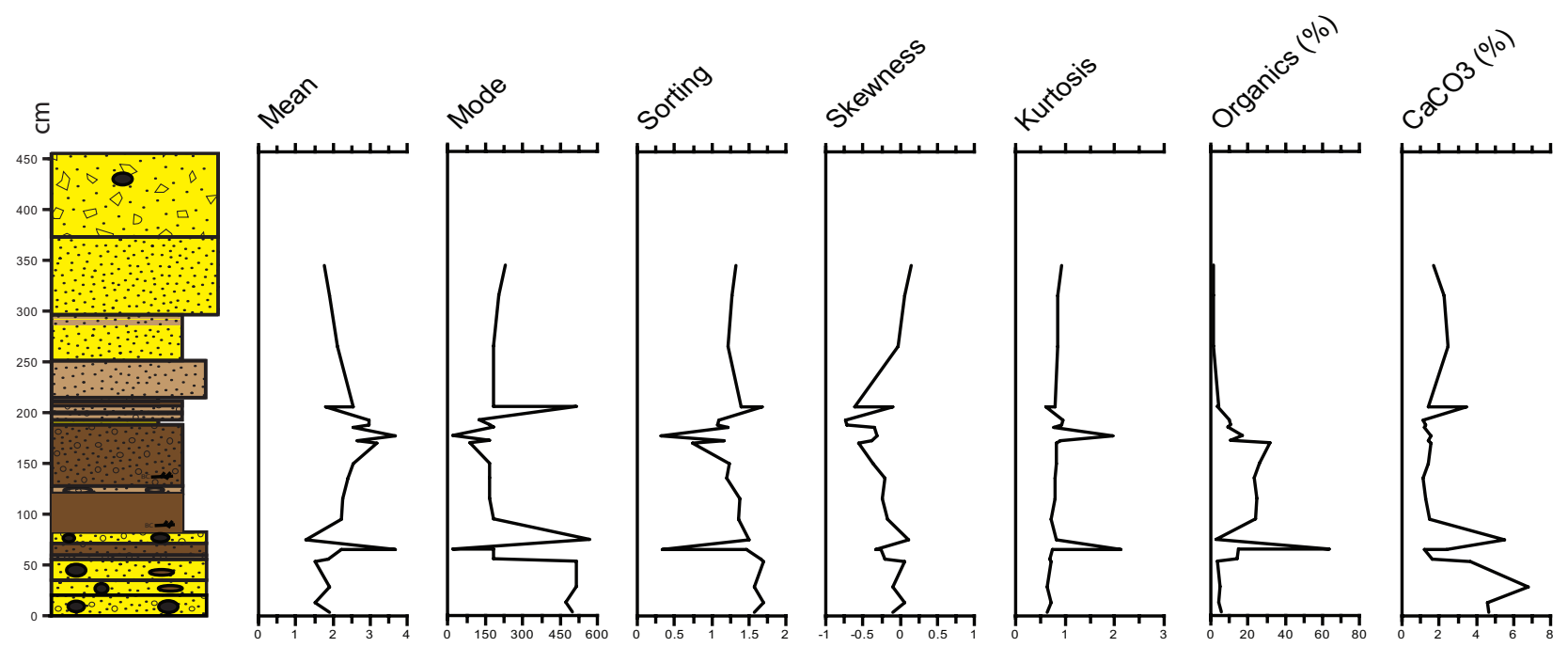

FIG. 7. Section A particle-size statistics and loss-on-ignition data correlated with the lithology of the section. Mean, sorting, skewness, and kurtosis are expressed in phi units $(\phi)$. Mode is expressed in microns. Sand is shown as yellow and peat as brown.

found at $49 \mathrm{~cm}$ in Section E, while Denticula sp. was found at $110 \mathrm{~cm}$ in Section C (Fig. 9A).

In the 1993 sample series collected by C.R. Harington, CR-93-10 and CR-93-59, a shift in diatom assemblage was also observed (Fig. 9B). The diatom community shifted from Staurosira-, Staurosirella- and Pseudostaurosira-dominated sections near the bottom $(92-192 \mathrm{~cm})$ to a community including Eunotia $(192-252 \mathrm{~cm})$, Brachysira $(210 \mathrm{~cm})$, and Pinnularia $(180-222 \mathrm{~cm})$ toward the top. Valves of Tabellaria sp. were found from 222 to $252 \mathrm{~cm}$, whereas Achnanthidium valves were observed only in the bottom sections $(72-172 \mathrm{~cm})$. Images of representative specimens are found within the online Appendix 1 (Figs. S1 and S2).

\section{Other Siliceous Microfossils}

Numerous other siliceous microfossils were observed from the Beaver Pond site sediments. Two freshwater sponge taxa (Porifera: Spongillidae) were identified by anatomical features of gemmoscleres and rotules. Ephydatia mülleri was the most abundant sponge microfossil $(\mathrm{n}=6)$ and was observed only in Section A. Many sponge megascleres and microscleres, which resembled Ephydatia mülleri, were observed in Section A, but most were broken, allowing only tentative identifications. One Ephydatia cf. fluviatilis specimen was found in Section A.

Chrysophyte cysts were common throughout Section A; however, these specimens remain unidentified. Cyst preservation varied from broken to perfect and their morphologies were spherical to oval, with variable pore morphologies. Some phytoliths were observed, and one protozoan (Protozoa: Rhizopoda) aperture plate was identified as Euglypha spp.

In the 1993 sample series CR-93-10 and CR-93-59, siliceous microfossils were recorded in all samples except the bottom level $(0 \mathrm{~cm})$. Siliceous thecal plates belonging to testate amoebae were present from $157 \mathrm{~cm}$ to $257 \mathrm{~cm}$.
A variety of plates were identified, indicating the presence of several genera, including Assulina, Euglypha, Lesquereusia, Nebela, Sphenoderia, and Trinema. Protozoan plates (thecamoebae) were present at low numbers $(\mathrm{n}<30)$, and no statistical analyses were conducted. The presence of these thecamoebae coincides with the shift of diatom assemblage.

\section{DISCUSSION}

\section{Paleoenvironmental Change}

Lithological changes coupled with microfossil evidence reveal a complex depositional history that shaped the Beaver Pond site. A basal flood plain environment, Unit I, was identified by the presence of poorly sorted sediments, including cobbles mixed with coarse sand, and the lack of sedimentary structures. The presence of the diatom Pinnularia borealis (an aerophilic species) also suggests that the area was either a wash zone or contained enough moisture to sustain diatom growth. Lenses of well-preserved peat (rip-up peats) indicate the presence of upstream peatcontaining wetlands in the form of moss-dominated wetlands characterized by low energy levels and little fluctuation in water level (Fig. 10, Unit I). Transportation of the peats likely occurred as periodic or seasonal flooding deposited these materials as overbank deposits. The source of the cobbles is uncertain. A cobble conglomerate layer separates the Paleocene-aged Mount Moore and Eocene-aged Margaret formations at Strathcona Fiord (Fig. 2) (Miall, 1986). In Strathcona Fiord, the "highterrace" deposits (a possible Beaufort Formation equivalent) overlie the Eureka Sound Group. However, Matthews and Ovenden (1990) suggested that the extent of the downcutting is not likely to have reached this cobble-rich boundary at Strathcona Fiord. Cobbles could have been transported either by ice or during seasonal high flows from 


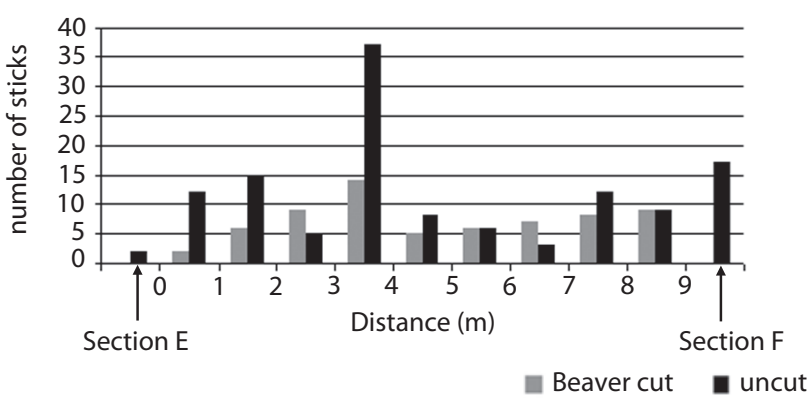

FIG. 8. Counts of beaver cut and uncut sticks within Unit III. Section A is located at $2 \mathrm{~m}, \mathrm{~B}$ at $4 \mathrm{~m}$, and $\mathrm{D}$ at $5 \mathrm{~m}$ distance from a reference point at the southeast end of the Beaver Pond site exposure.

draining glaciers. The combined evidence suggests that Unit I represented a floodplain that was occasionally flooded by a river system and that the sediment source may have been of fluvio-glacial origin (Fig. 10, Unit I).

Unit II is a peat unit with minor amounts of siliciclastic sediment. The uniform and small sediment size in Unit II indicates that the sediment source is consistent and unchanged throughout (Fig. 10, Unit II). The diatom taxa found in the transition from Unit I to Unit II indicate that the environment was circumneutral and oligotrophic. The peat in Unit II may have formed because an increase in the local water table created an isolated rich fen.

Unit III is the main peat interval $(25 \%-30 \%$ organic content) that includes poorly sorted sediment, suggesting influence from an outside sediment source, possibly in the form of short-lived precipitation events (Fig. 10, Unit III). The dominant bryophyte, Scorpidium scorpioides, indicates that Unit III was a rich fen. Fens are open peatland systems that are minerotrophic and alkaline in nature, receiving most of their water supply from groundwater (Mitsch et al., 2009). They are dominated by brown mosses (species in the family Amblystegiaceae s.1.); Scorpidium scorpioides is one of the most common species in modern mineral-rich fens of the Northern Hemisphere (Kooijman and Paulissen, 2006). A minerotrophic fen may develop into an ombrotrophic (precipitation-fed) bog over time; as the organic content increases and the $\mathrm{pH}$ decreases, the fen becomes more acidic, eventually becoming dominated by sphagnum mosses and other plants typical of poor fens or bogs (Kooijman and Paulissen, 2006; Miller and Nestor, 2006; Mitsch et al., 2009). The peat at the Beaver Pond site may have formed in a shallow area or as a floating mat (Ovenden, 1993). In either case, the rich assemblage of terrestrial mammals in the peat suggests a nearshore riparian environment. The cobbles present within the thickest part of the peat (area of Section A) may be dropstones derived from ice-rafting (C.R. Harington field notes, 2001). A fossil occurrence of a $20 \mathrm{~cm}$ long percid fish within the thickest peat suggests a connection with a larger water body (Murray et al., 2009). Rich fens are slightly alkaline environments, which possibly accounts for the excellent preservation of bones at the Beaver Pond site (Sharitz and Pennings, 2006). The diatom assemblage suggests a change to an increasingly acidic environment towards the top of this unit, perhaps marking succession to poor fen or more bog-like conditions. Today, forested fens are usually dominated by spruce (Picea sp.) and larch (Larix sp.), which are often found in stunted condition (Sharitz and Pennings, 2006). At the Beaver Pond site, larch trees (the extinct species, Larix groenlandii) have been identified, and some were stunted (Matthews and Ovenden, 1990; Ovenden, 1993).

The greatest thickness of peat attributed to Unit III (now excavated, see Fig 3A) was $240 \mathrm{~cm}$ and is estimated to represent approximately $49000 \pm 12000$ years (Table 3). Many modern fens are around 10000 years old, having been initiated after the most recent glacial (Yu et al., 2003; Yu, 2006; Jones and $\mathrm{Yu}, 2010$ ), and peatland formation has also been associated with Quaternary interglacial climate (e.g., Schokker et al., 2004). If the estimates presented here for the Beaver Pond site peat unit are correct, it is possible that the duration time represented in the Beaver Pond peat unit is evidence of an extended Pliocene interglacial/warm phase.

Many of the diatom taxa and associated generic groups observed during the Pliocene are found today from the northern United States to Ellesmere Island (Camburn and Charles, 2000; Antoniades et al., 2008; Lavoie et al., 2008). Although some species and species groups are biogeographically similar, the overall biodiversity of today's northern tundra lakes and ponds differs from region to region. Staurosiroids, which typically dominate the presentday diatom communities across the Canadian Arctic Archipelago, indicate the colder climate of the receding Little Ice Age (Wolfe, 2000; Paull et al., 2008). The duration of 49000 years for the Beaver Pond site peat unit is similar to the established orbital-based Pliocene climate oscillations of 41000 years, supporting the notion that the region likely experienced changing climate during this time. The later presence of raphid diatoms like Eunotia and Pinnularia throughout Unit III $(192-252 \mathrm{~cm})$ could indicate the establishment of a larch-dominated forest under warmer conditions (Ford, 1990; Matthews and Ovenden, 1990). The uppermost peat (top of Unit III into Unit IV) is dominated by the Eunotia species, which include E. incisa (presentday pH optima 5.2-5.3 \pm 0.8 ) (Siver et al., 2005; Siver and Hamilton, 2011). Eunotia glacialis occurs in minerotrophic peat bog complexes of moderately low $\mathrm{pH}$ and conductivity, which suggests that the Beaver Pond site may not have been ombrotrophic (Lange-Bertalot et al., 2011). Eunotia taxa have been present on the North American continental plate since the Eocene and are a good proxy for paleoclimate changes (Siver and Wolfe, 2007). Further, the presence, although rare, of Meridion circulare, Rhopalodia, and Synedra in the mid-section of Unit III indicates circumneutral to slightly alkaline waters. In addition, the freshwater sponge Ephydaita mulleri found throughout the peats at the Beaver Pond site is a Holarctic taxon that prefers a slightly acidic dystrophic habitat (Økland and Økland, 1996; Frost et al., 2001). 


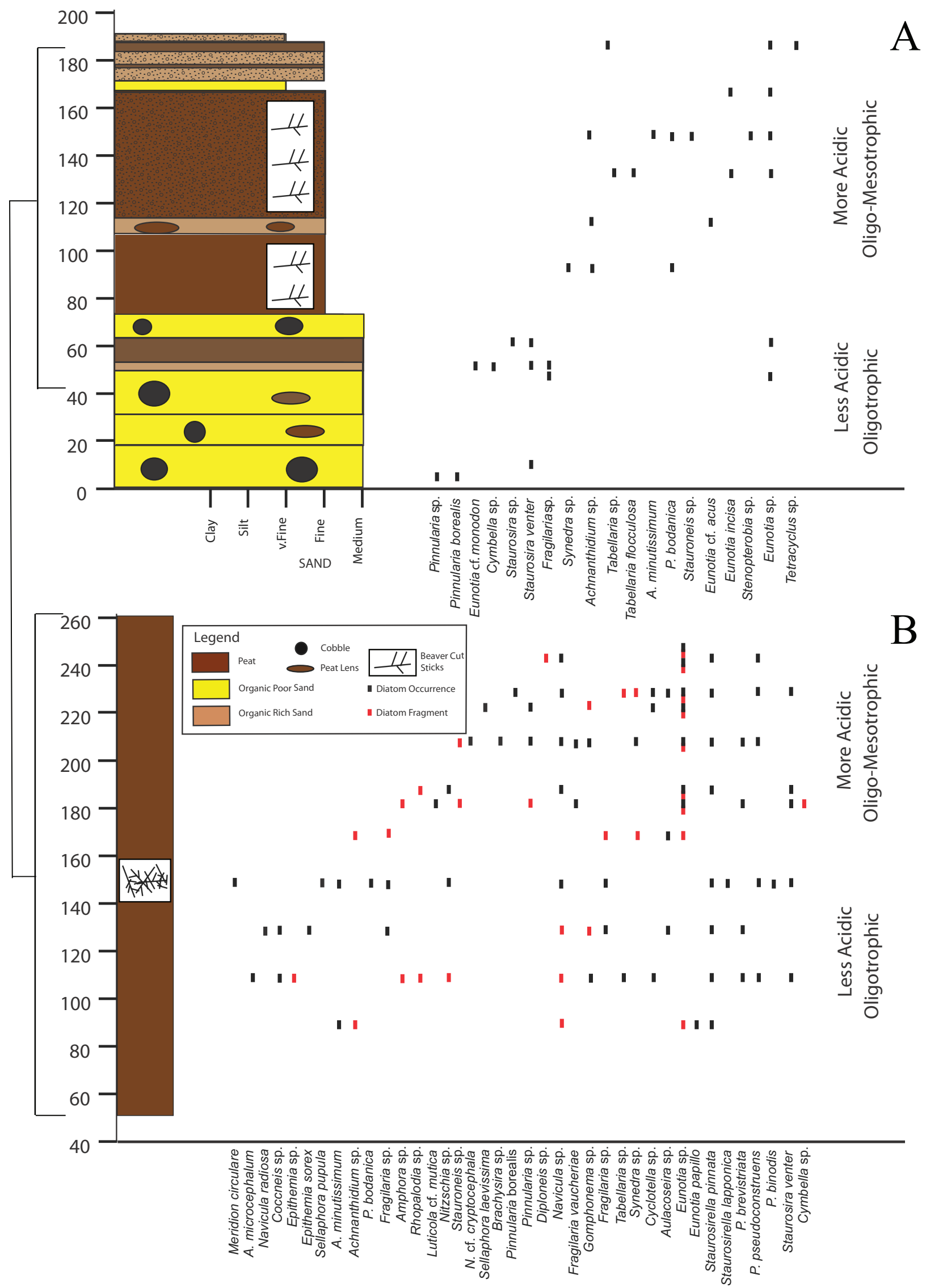

FIG. 9. Stratigraphy, diatoms, and environmental interpretations for Section A. Symbols: Yellow = Sand; Brown = peat (darker colours are more organic-rich); Black ellipses = cobbles; bifurcating icons $=$ beaver-cut sticks. 

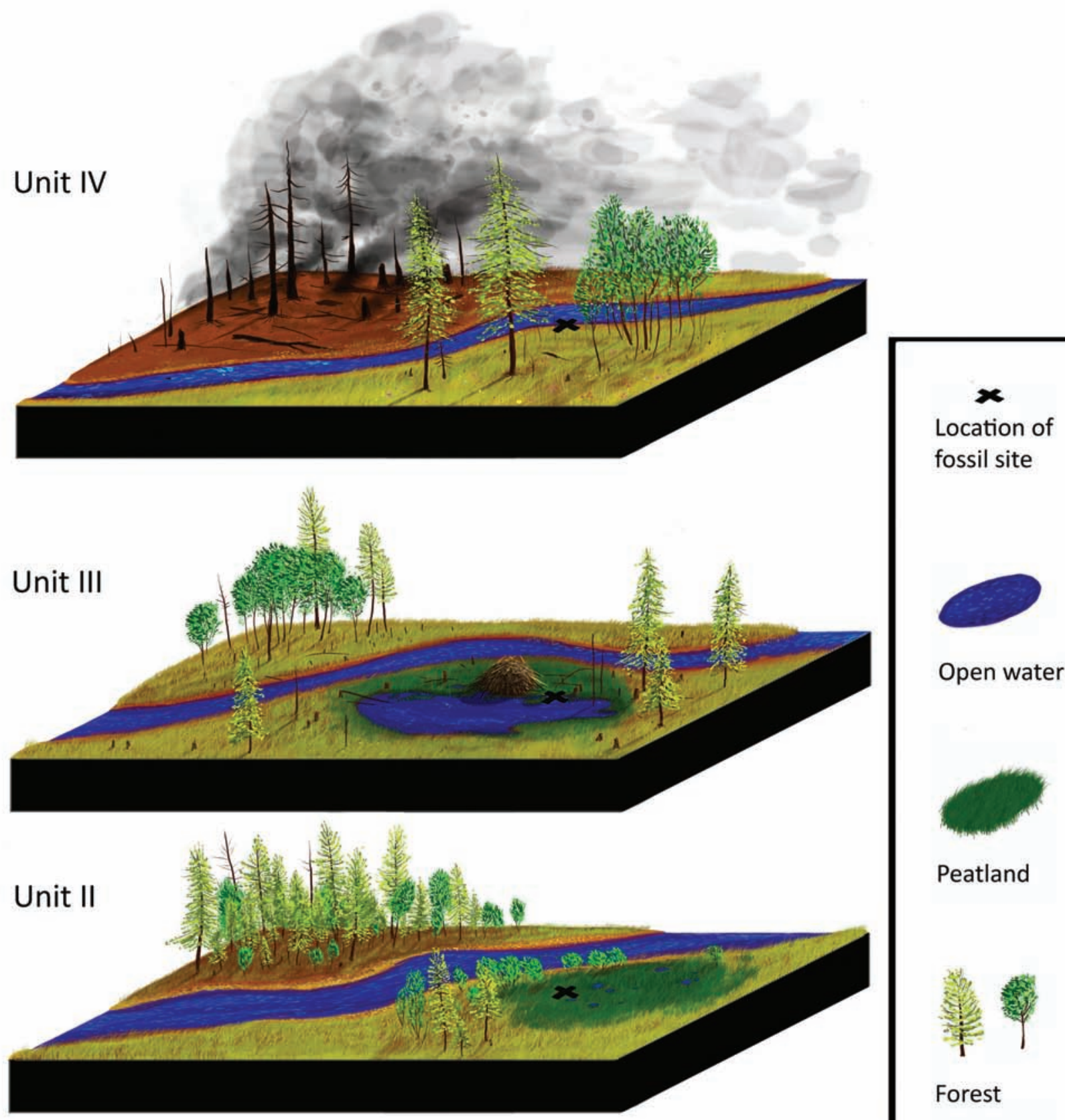

Location of

fossil site

Peatland

Open water

\section{Peatland}

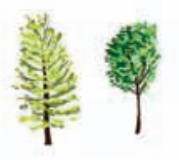

Forest

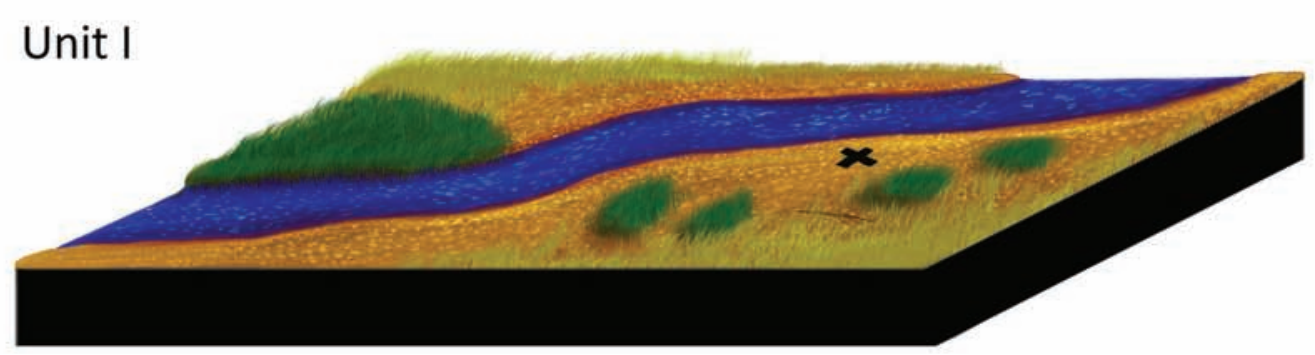

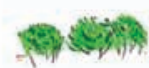

Shrubs

FIG. 10. Interpretation of environmental change that occurred at the Beaver Pond site, correlated with the stratigraphic units from earliest (Unit I) to latest (Unit IV). Unit I: The site is located in a cobbled floodplain, and nearby peatlands are in contact with the river upstream, providing a source for small lenses of peat that are delivered to the floodplain by the river. Unit II: The site is located within a laterally extensive peatland on a floodplain with shrubs and trees. River flooding events bring cobbles into the peatland. Unit III: The site is located within a peatland connected to open water. There is evidence of forest, although early in the formation of Unit III, immediate surroundings were more tundra-like (not shown). This unit includes concentrated beaver activity (i.e., beaver-cut wood) and sediment input from the surrounding floodplain. Peat growth was locally enhanced by water pooling that in turn might have been enhanced by beaver activity. Unit IV: The site is formed adjacent to a small creek. Nearby forest fires create a charcoal-rich overbank deposit that appears finer grained because increased soil formation supports an increasing vegetation cover. 
Monoraphid diatoms (e.g., Achnanthidium, Cocconeis), which require attachment to the benthos and other substrata, were consistently observed in the lower sections $(72-172 \mathrm{~cm})$ and are indicative of flowing shallow waters with good light conditions. The progression of diatom changes through Unit III (benthic attached forms to acidic forms) supports the idea of an earlier harsh, "tundra-like" environment that changed through time to more stable terrestrial environments. In addition, inferred water chemistry further supports the notion that the Beaver Pond site had boreal conditions. This notion, in turn, is supported by the observation of peat accumulation in the upper sections of Unit III and increased protozoan activity. Diatom richness was highest in the mid-portion of Unit III $(92-222 \mathrm{~cm})$, suggesting a succession from tundra-like conditions to a more boreal-forest type environment. The mid-period of peat accumulation is the period of highest diatom species richness $(92-222 \mathrm{~cm})$, and likely the period of greatest habitat stability. One might hypothesize that the stick accumulation in the upper half of the peat of Unit III contributed to the formation and stability of the small lake (see discussion below).

Changes in the carbonate and organic matter composition (Fig. 7) also indicate that $\mathrm{pH}$ is reduced toward the top of Unit III. There are three sources of carbonate in freshwater lakes: production of skeletal elements, support structures, and byproducts of living organisms; inorganic precipitation of carbonate minerals; and allochthonous carbonate transported into the lake (Kelts and Hsü, 1978). As organic matter exceeds $12 \%$, the $\mathrm{pH}$ decreases to a point at which calcium carbonate at the sediment-water interface dissolves (Dean, 1999). Organic content of the Beaver Pond peat in Unit III was consistently greater than 20\% (Fig. 7), which supports the interpretation of a lower $\mathrm{pH}$ during the period of peak peat accumulation. In combination, the low organic content and consistent carbonate content throughout the peat accumulation interval show that $\mathrm{pH}$ levels were potentially variable, but more acidic than alkaline. Extreme acidity can also be excluded since vertebrate fossils are preserved well in Unit III. However, towards the top of Unit III (from 180 to $250 \mathrm{~cm}$ ) the decline in organic content indicates a long period of change with uncertain $\mathrm{pH}$ conditions. The relative $\mathrm{pH}$ of the water did decrease, and the presentday diatom analog suggests that it was likely between 5.0 and 6.5, which limited carbonate precipitation (Fig. 7). Surface water of rich fens is typically mildly acidic to basic, with $\mathrm{pH}$ greater than 5.8 (Miller, 1980), although fens in general can have water conditions ranging from acidic to alkaline ( $\mathrm{pH} 4.2$ to 7.2, depending on whether they are poor or rich) (Miller and Nestor, 2006). Diatom taxa also indicate that the paleoenvironment of Unit III became slightly more nutrient rich compared to Units I and II. The presence of the centric diatom Puncticulata bodanica suggests that a deeper water, lentic (= standing water) aquatic system existed at or close to the Beaver Pond site (Fig. 10, Unit 3).

The appearance of siliceous protozoan plates at $100 \mathrm{~cm}$ and increased abundances at $130-200 \mathrm{~cm}$ could indicate changes in peat-forming ontogeny that coincide with changes in the diatom flora. Douglas and Smol (1987) demonstrated how the appearance and marked increase in protozoan plates in sedimentary deposits reflected bog formation. In this study, an increase in moss abundance is inferred from the appearance and presence of protozoan plates as well as from shifts in diatom assemblages (Figs. 9A, B).

The peat-rich Unit III varies laterally across the site (Fig. 5). Spatial variability in wetland environments is a factor that may explain some of the patterns observed in the occurrence of peat and peat types across the section, changing from moss-dominated peat with aquatic plants to a more terrestrial signal, with Betula and ericaceous shrubs such as Vaccinium. Studies of Eocene fossil forest swamps in the Arctic have demonstrated the importance of considering lateral variation due to small-scale changes in hydrology in characterizing wetland paleoenvironments as mosaic plant communities (Greenwood and Basinger, 1993). Modern wetland environments are dynamic ecosystems subject to changes in seasonal and annual hydrological regimes, which create a mosaic landscape with a shifting aquatic/terrestrial interface. The variation in peat types observed in the section at the Beaver Pond site may reflect this type of mosaic landscape in the paleo-wetland environment. As we see more evidence of terrestrial plant species in the upper part of Unit III, and particularly in Section C, it may represent encroachment and colonization of species from surrounding areas. This encroachment would occur within the ebb and flow of an open, patchy wetland environment as changing soil and hydrologic conditions at the local scale favour a different plant community composition.

The sharp transition between Units III and IV signals a significant paleoenvironmental change that resulted in reduced peat accumulation. In Unit IV, there are no sedimentary structures within the sandy matrix, but the alignment of twigs and organic matter suggests flow in a small stream (Fig. 10, Unit IV). The presence of cones and other organic matter, as well as an abundance of charcoal within the layer, further suggests the establishment of nearby forested areas and subsequent forest fires (note that some of the beaver-cut sticks and tree trunks show evidence of burning as well). Extensive forest fires can alter the hydrologic conditions of a region by increasing runoff and streamflow volumes and may have contributed to the end of peat formation at the Beaver Pond site. Evidence of extensive Pliocene coal seam fires was reported from the Vendom Fiord area, $130 \mathrm{~km}$ south of Strathcona Fiord, on Ellesmere Island (dated $3.3 \pm 0.5 \mathrm{MY}$ ) (Estrada et al., 2009). In severe peatland fires, combustion of the peat is common (Turetsky and St. Louis, 2006). However, the presence of only a small amount of charcoal at the Beaver Pond site suggests that combustions of the peat did not occur at this locality. Forest fires are known to decrease the occupancy rate of modern beaver colonies (Hood et al., 2007). Fires may have been a factor in the abandonment of beaver activity at the Beaver Pond site, which was followed by the reestablishment of a small fluvial system. 
Previous work has suggested that the Beaver Pond site may have been greatly affected by slumping (Matthews and Ovenden, 1990: Fig. 11). Our fieldwork found evidence to suggest that the thickest peat was not slumped. This implies that at least one sample (i.e., sample 88-51b, in Matthews and Ovenden, 1990: Fig. 11), previously considered to be part of the "Beaver Peat" layer (i.e., Unit III in this study), was derived instead from a peat layer that is stratigraphically higher in the deposit than the layers being studied here. Future research efforts involving this site should consider the possibility that the taxonomic diversity of the "Beaver Peat" described in past publications (Matthews and Ovenden, 1990; Matthews and Fyles, 2000) may reflect samples derived from different peat layers and possibly representing different climate regimes.

\section{Role of Beavers in the Pliocene High Arctic}

The presence of numerous beaver bones, well-preserved beaver-cut sticks concentrated in Sections A, B, D, (Fig. 3C, D), and evidence of possible beaver-made structures (Tedford and Harington, 2003) points towards the role of beavers in the Pliocene High Arctic environment. Modern beavers (genus Castor) are considered "keystone species" and "ecosystem engineers" because of the role they play in modifying landscapes and ecosystems (Naiman et al., 1986; McKinstry et al., 2001; Odling-Smee et al., 2003). Modern beavers do not hibernate. Instead, in harsh winter climates, they survive by feeding on branches from underwater food piles that they construct each year before the onset of winter (Nowak, 1999). The dams are maintained over many years and have a tremendous effect on the local environment, creating open vegetation areas, trapping sediment, reducing stream velocity, changing channel patterns, and contributing to the creation and maintenance of wetlands (Butler, 1995; Butler and Malanson, 1995, 2005; Green and Westbrook, 2009).

Currently, the Beaver Pond site is the only fossil site that preserves evidence of an extinct beaver genus associated with evidence of construction behavior involving cut wood. Although Castor existed in the Pliocene of Eurasia and North America (Rybczynski et al., 2010), the fossil beaver remains found at the site belong to the genus Dipoides. Dipoides was slightly smaller than the modern Castor, and the cut marks on the wood clearly match the incisors of this genus (Rybczynski, 2008). Dipoides is known from the Neogene of North America, Europe, and Asia (Flynn and Jacobs, 2008) and is a distant relative of Castor, whereas Castoroides, the Pleistocene giant beaver, is more closely allied with Dipoides, according to the tooth pattern (Harington, 1996). Phylogenetic and fossil behavioral evidence suggest that Dipoides and Castor shared a common ancestor that existed at least 23 million years ago. This common ancestor was semiaquatic, wood-cutting, and probably lived in multigenerational family groups (Hugueney and Escuillié, 1995; Rybczynski, 2007). Swimming and woodcutting are prerequisites for the evolution of lodge and dam building behavior, so it is possible that this common ancestor might also have been building some sort of structure, such as lodges or dams.

Today, beavers are often associated with peatland environments. Peatlands are commonly initiated before beavers enter the system (Gorham et al., 2007); however, beaver activity can create water-level changes conducive to wetland formation (Westbrook et al., 2006). Once a peatland is established, beavers dig canals and help to create and maintain deep, open water by damming seepage (Westbrook et al., 2013). Canals are routes of open water used by the beaver to transport branches and logs. Canals can also divert water into a pond, maintaining its water depth (Butler, 1995).

The thick peat layer found in Unit III represents accumulation of peat over thousands of years, which no single dam could have caused. We propose that the peat unit was maintained primarily by topography rather than a dam (Fig. 10). With a mean annual temperature around freezing, the Beaver Pond site was in a zone where sporadic discontinuous permafrost might have occurred. It is therefore possible that the depression might have been created through thermokarst processes. The presence of Dipoides remains at various levels in the peat suggests that this beaver occupied the area multiple times through the peatforming interval. Dipoides may have influenced the local environment, creating open water conditions intermittently through its activities, which may have included dam-building. The "possible core of a dam" described by Tedford and Harington (2003:389) was located within the thickest part of the Unit III peat layer, $91 \mathrm{~cm}$ above the base of the peat (Fig. 6), along with a partial Dipoides skeleton and possible feeding pile, all at a similar level. Interestingly, by far the greatest concentration of diatoms was recorded at depths of $100 \mathrm{~cm}$ and $80 \mathrm{~cm}$ above the base of the peat, which suggests that beaver activity was coincident with continuous aquatic conditions. The mass that appears to be remnants of a dam comprised approximately seven sticks with beaver cut-marks and five cobbles embedded within an organicrich, sandy silt, all of which was, in turn, embedded within the peat. The sticks were found lying crosswise to each other and the largest stick was $72 \mathrm{~cm}$ long and $5 \mathrm{~cm}$ in diameter (Tedford and Harington, 2003; C.R. Harington, 2001 field notes). The length of the entire mass of sticks, cobbles, and sediment was about $1 \mathrm{~m}$ (Harington, 2001 field notes). Today, Castor is known to use cobbles in the construction of its dams (Wilsson, 1971), and cobbles are common in modern peatland dams (C.J. Westbrook, pers. comm. 2012). Also, the presence of a silty sand matrix around the sticks and cobbles is consistent with beaver construction activity, as beavers today are known to use sediment to pack the dam (or lodge) (Wilsson, 1971). Often beaver dams are associated with a layer of accumulated sediment because a stream, when impeded, will drop its sediment load. At the Beaver Pond site, there does not seem to have been evidence of sediment accumulation associated with the dam-like structure (C.R. Harington, pers. comm. 2015). 
However, it has been observed that in modern beaverinhabited peatlands, the dams function to pool low-energy water seepage (Westbrook et al., 2013). A low-energy seepage flow is unlikely to carry much sediment, so that in the context of a peatland, it might be expected that beaver dams should be associated with a lack of sediment accumulation. The mass discovered in 2001 was excavated and removed soon after. More recent excavations (2006-10) have yielded another small accumulation of beaver-cut sticks nearer to the top of the peat unit (Fig. 3C and D) that may also have resulted from some kind of construction activity.

Whether by dam building, canal construction, or both, it is possible that the activities of Dipoides intermittently over thousands of years contributed to the creation of open water. The presence of open water within the peatland unit (Fig. 10, Unit III) is evidenced by the planktonic diatoms (Aulacoseira, Cyclotella, Puncticulata) reported here and the presence of a large perciform fish (Murray et al., 2009). The rich fossil vertebrate assemblage found at the site (see Introduction) may itself be significant in the context of beaver-modified habitat. As with modern beavers, changing their environment from a lotic (i.e., moving water) to a lentic (i.e., still water) system will create new biological conditions that support a much wider array of wildlife (Collen and Gibson, 2001). It is possible that the presence of Dipoides may have contributed to the creation of a habitat that could explain the rich collection of Pliocene vertebrate fossils found at this locality.

\section{CONCLUSIONS}

This study has provided the first systematic description of the stratigraphy and depositional environment of the Beaver Pond site, bringing together several lines of evidence including lithology, organic and carbonate content, diatom assemblages, plant community composition, and paleoecology of beaver activity.

A model is proposed to explain the evolution of the site from a floodplain environment to the development of a fen peatland with intermittent beaver activity. Over time, the site became more acidic, suggesting a shift from rich fen to more bog-like conditions, and colonization by terrestrial plants typical of acidic, wet soils of northern peatlands such as larch, birch, and ericaceous shrubs. We interpret the "fine-grain" change in local environment and water conditions as being driven primarily by in situ biological successional processes (i.e., wetland succession). However, the thickness of the peat unit, coupled with higher diatom diversity in the upper sections, may also reflect an increase in productivity related to climate change. The original peat layer at the Beaver Pond site was $240 \mathrm{~cm}$ thick (Fig. 3A). Using Holocene northern boreal forest fens as an analogue, we provide a preliminary estimate that this thickness of peat represents $49077 \pm 11997$ years of growth. During the Pliocene, glacial-interglacial climate cycles were dominated by a 41 ka periodicity (Lisiecki and Raymo, 2007). If the estimate provided here for the peat duration is accurate, it suggests that the peatland, for at least some period, grew during an extended warm interglacial interval, (i.e., longer than a typical Pliocene interglacial phase). Finally, the unit overlying the peat layer bears evidence of fires linked to a prominent carbon source independent of the peat (i.e., a terrestrial forest), followed by the reestablishment of a small, less productive, fluvial system.

\section{ACKNOWLEDGEMENTS}

This manuscript derives from an MSc thesis by W.T. Mitchell (Carleton University, Earth Sciences), and we thank the thesis committee for their input. Integral to this project was C.R. Harington (Canadian Museum of Nature, CMN), who led the original field expeditions and research of the Beaver Pond fossil site, beginning in 1992. He also collected samples reported here and provided discussions that guided the formulation of the thesis and this manuscript. P. Bloskie (CMN) collected surface scanning data for the peat density calculations. Glenn Poirier provided support with the use of the scanning electron microscope and mineral identifications. Michael Pisaric (Carleton University), J. Gosse (Dalhousie University), Alice Telka (Paleotec Services), and Cherie Westbrook (University of Saskatchewan) provided many helpful discussions. Alan McDonald (CMN) produced Figure 1, and Stefan Thompson provided the graphic for Figure 10. The fieldwork was supported by a paleontology permit from the Government of Nunavut (Department of Culture, Language, Elders and Youth) and with the permission of the Qikiqtani Inuit Association and especially the community of Grise Fiord (Nunavut). Logistic support was provided by the Polar Continental Shelf Program. Student travel support was provided to W.T. Mitchell by the Northern Scientific Training Program (Aboriginal Affairs and Northern Development Canada). Thanks to the field crew members M.A. Gilbert (CMN), M.E. Lipman, and J. Gosse (Dalhousie University). This research was also supported by the Canadian Museum of Nature, NSERC Discovery grants to C. Schröder-Adams and N. Rybcznski, and support from the Garfield Weston Foundation to N. Rybcznski.

\section{APPENDIX 1}

The following figures are available in a supplementary file to the online version of this article at:

http://arctic.journalhosting.ucalgary.ca/arctic/index.php/ arctic/rt/suppFiles $/ 4567 / 0$

FIG. S1. Diatom taxa from the Beaver Pond fossil site: 1-3) Staurosira venter; 4-6) Fragilarioid taxa; 7) Fragilaria sp. (side view); 8) Cymbella sp.; 9-10) Achnanthidium sp.; 11) Tabellaria flocculosa; 12) Tabellaria sp. fragment. Scale bars $=5 \mu \mathrm{m}$.

FIG. S2. Diatom taxa recovered from the Beaver Pond fossil site: 1-2) Eunotia glacialis; 3-4) Eunotia incisa; 5-6) Eunotia sp.; 7) Pinnularia borealis; 8) Ellerbeckia arenaria; 9-11) Puncticulata bodanica. Scale bars $=5 \mu \mathrm{m}$. 


\section{REFERENCES}

Antoniades, D., Hamilton, P.B., Douglas, M.S.V., and Smol, J.P. 2008. Diatoms of North America: The freshwater floras of Prince Patrick, Ellef Ringnes and northern Ellesmere Islands from the Canadian Arctic Archipelago. Iconographia Diatomologica 17. 649 p.

Arius3D. 2007. Pointstream 3DImageSuite for Windows ${ }^{\circledR}$, Version 2.7. Mississauga, Ontario: Arius3D Inc.

Ballantyne, A.P., Rybczynski, N., Baker, P.A., Harington, C.R., and White, D. 2006. Pliocene Arctic temperature constraints from the growth rings and isotopic composition of fossil larch. Palaeogeography, Palaeoclimatology, Palaeoecology 242 (3-4): $188-200$. http://dx.doi.org/10.1016/j.palaeo.2006.05.016

Ballantyne, A.P., Greenwood, D.R., Sinninghe Damsté, J.S., Csank, A.Z., Eberle, J.J., and Rybczynski, N. 2010. Significantly warmer Arctic surface temperatures during the Pliocene indicated by multiple independent proxies. Geology 38(7):603-606. http://dx.doi.org/10.1130/G30815.1

Brigham-Grette, J., Melles, M., Minyuk, P., Andreev, A., Tarasov, P., DeConto, R., Koenig, S., et al. 2013. Pliocene warmth, polar amplification, and stepped Pleistocene cooling recorded in NE Arctic Russia. Science 340(6139):1421 - 1427. http://dx.doi.org/10.1126/science.1233137

Butler, D.R. 1995. Zoogeomorphology: Animals as geomorphic agents. New York: Cambridge University Press. 231 p. http://dx.doi.org/10.1017/CBO9780511529900

Butler, D.R., and Malanson, G.P. 1995. Sedimentation rates and patterns in beaver ponds in a mountain environment. Geomorphology 13(1-4):255-269. http://dx.doi.org/10.1016/0169-555x(95)00031-y

- 2005. The geomorphic influences of beaver dams and failures of beaver dams. Geomorphology 71(1-2):48-60. http://dx.doi.org/10.1016/j.geomorph.2004.08.016

Camburn, K.E., and Charles, D.F. 2000. Diatoms of low-alkalinity lakes in the northeastern United States. Special Publication 18. Philadelphia: Academy of Natural Sciences of Philadelphia. $152 \mathrm{p}$.

Collen, P., and Gibson, R.J. 2001. The general ecology of beavers (Castor spp.), as related to their influence on stream ecosystems and riparian habitats, and the subsequent effects on fish - a review. Reviews in Fish Biology and Fisheries 10(4):439-461. http://dx.doi.org/10.1023/A:1012262217012

Csank, A.Z., Patterson, W.P., Eglington, B.M., Rybczynski, N., and Basinger, J.F. 2011a. Climate variability in the Early Pliocene Arctic: Annually resolved evidence from stable isotope values of sub-fossil wood, Ellesmere Island, Canada. Palaeogeography, Palaeoclimatology, Palaeoecology 308(3-4): $339-349$.

http://dx.doi.org/10.1016/j.palaeo.2011.05.038

Csank, A.Z., Tripati, A.K., Patterson, W.P., Eagle, R.A., Rybczynski, N., Ballantyne, A.P., and Eiler, J.M. 2011 b. Estimates of Arctic land surface temperatures during the early Pliocene from two novel proxies. Earth and Planetary Science Letters 304(3-4):291-299.

http://dx.doi.org/10.1016/j.epsl.2011.02.030
Davies, N.S., Gosse, J.C., and Rybczynski, N. 2014. Cross-bedded woody debris from a Pliocene forested river system in the High Arctic: Beaufort Formation, Meighen Island, Canada. Journal of Sedimentary Research 84(1):9-25.

http://dx.doi.org/10.2110/jsr.2014.5

Dawson, M.R., and Harington, C.R. 2007. Boreameryx, an unusual new artiodactyl (Mammalia) from the Pliocene of Arctic Canada and endemism in Arctic fossil mammals. Canadian Journal of Earth Sciences 44(5):585 - 592. http://dx.doi.org/10.1139/e06-111

Dean, W.E. 1999. The carbon cycle and biogeochemical dynamics in lake sediments. Journal of Paleolimnology 21(4):375-393. http://dx.doi.org/10.1023/A:1008066118210

Douglas, M.S.V., and Smol, J.P. 1987. Siliceous protozoan plates in lake sediments. Hydrobiologia 154(1):13-23. http://dx.doi.org/10.1007/bf00026827

. 2002. Siliceous protozoan plates and scales. In: Smol, J.P., Birks, H.J.B., and Last, W.M., eds. Tracking environmental change using lake sediments: Vol. 3: Terrestrial, algal, and siliceous indicators. Developments in Paleoenvironmental Research, Vol. 3. Dordrecht, The Netherlands: Kluwer Academic Publishers. 265-279.

http://dx.doi.org/10.1007/0-306-47668-1_13

Dowsett, H.J., Robinson, M.M., Haywood, A.M., Hill, D.J., Dolan, A.M., Stoll, D.K., Chan, W.L., et al. 2012. Assessing confidence in Pliocene sea surface temperatures to evaluate predictive models. Nature Climate Change 2(5):365 - 371 . http://dx.doi.org/10.1038/nclimate1455

Elias, S.A., and Matthews, J.V., Jr. 2002. Arctic North American seasonal temperatures from the latest Miocene to the Early Pleistocene, based on mutual climatic range analysis of fossil beetle assemblages. Canadian Journal of Earth Sciences 39(6):911-920.

http://dx.doi.org/10.1139/e01-096

Environment Canada. 2015. Canadian climate normals 1971-2000 station data.

http://climate.weather.gc.ca/climate_normals/results_e. html?stnID=1750\&autofwd=1

Estrada, S., Piepjohn, K., Frey, M.J., Reinhardt, L., Andruleit, H., and von Gosen, W. 2009. Pliocene coal-seam fires on southern Ellesmere Island, Canadian Arctic. Neues Jahrbuch für Geologie und Palaontologie - Abhandlungen 251(1):33 - 52. http://dx.doi.org/10.1127/0077-7749/2009/0251-0033

Etzler, F.M., and Deanne, R. 1997. Particle size analysis: A comparison of various methods ii. Particle \& Particle Systems Characterization 14(6):278-282.

http://dx.doi.org/10.1002/ppsc.19970140604

Falcon-Lang, H.J., MacRae, R.A., and Csank, A.Z. 2004. Palaeoecology of Late Cretaceous polar vegetation preserved in the Hansen Point Volcanics, NW Ellesmere Island, Canada. Palaeogeography, Palaeoclimatology, Palaeoecology 212(1-2): $45-64$. http://dx.doi.org/10.1016/j.palaeo.2004.05.016

Flynn, L.J., and Jacobs, L.L. 2008. Castoroidea. In: Janis, C.M., Gunnell, G.F., and Uhen, M.D., eds. Evolution of Tertiary mammals of North America, Vol. 2: Small mammals, xenarthrans, and marine mammals. Cambridge: Cambridge University Press. 391-405. 
Ford, M.S.J. 1990. A 10000-yr history of natural ecosystem acidification. Ecological Monographs 60(1):57-89. http://dx.doi.org/10.2307/1943026

Francis, J.E. 1988. A 50-million-year-old fossil forest from Strathcona Fiord, Ellesmere Island, Arctic Canada: Evidence for a warm polar climate. Arctic 41(4):314-318. http://dx.doi.org/10.14430/arctic1738

Frost, T.M., Reiswig, H.M., and Ricciardi, A. 2001. Porifora. In: Thorp, J.H., and Covich, A.P., eds. Ecology and classification of North American freshwater invertebrates, $2^{\text {nd }}$ ed. New York: Academic Press. 97-133. http://dx.doi.org/10.1016/B978-012690647-9/50005-3

Fyles, J.G. 1990. Beaufort Formation (Late Tertiary) as seen from Prince Patrick Island, Arctic Canada. Arctic 43(4):393 - 403. http://dx.doi.org/10.14430/arctic1632

Fyles, J.G., Hills, L.V., Mathews, J.V., Jr., Barendregt, R.W., Baker, J., Irving, E., and Jetté, H. 1994. Ballast Brook and Beaufort Formations (Late Tertiary) on northern Banks Island, Arctic Canada. Quaternary International 22-23:141-147. http://dx.doi.org/10.1016/1040-6182(94)90010-8

Gajewski, K., Hamilton, P.B., and McNeely, R. 1997. A highresolution proxy climate record from an Arctic lake with annually-laminated sediments on Devon Island, Nunavut, Canada. Journal of Paleolimnology 17(2):215-225. http://dx.doi.org/10.1023/A:1007984617675

Gladenkov, A.Y., Oleinik, A.E., Marincovich, L., Jr., and Barinov, K.B. 2002. A refined age for the earliest opening of Bering Strait. Palaeogeography, Palaeoclimatology, Palaeoecology 183(3-4):321-328. http://dx.doi.org/10.1016/S0031-0182(02)00249-3

Gorham, E., Lehman, C., Dyke, A., Janssens, J., and Dyke, L. 2007. Temporal and spatial aspects of peatland initiation following deglaciation in North America. Quaternary Science Reviews 26(3-4):300-311.

http://dx.doi.org/10.1016/j.quascirev.2006.08.008

Green, K.C., and Westbrook, C.J. 2009. Changes in riparian area structure, channel hydraulics, and sediment yield following loss of beaver dams. BC Journal of Ecosystems \& Management 10(1):68-79.

Greenwood, D.R., and Basinger, J.F. 1993. Stratigraphy and floristics of Eocene swamp forests from Axel Heiberg Island, Canadian Arctic Archipelago. Canadian Journal of Earth Sciences 30(9):1914-1923.

http://dx.doi.org/10.1139/e93-169

Harington, C.R. 1996. Giant beaver. Beringian Research Notes $6: 1-4$

- 2001. Life at a 3.5 million-year-old beaver pond in the Canadian Arctic Islands and the modern scene. Meridian (Fall/ Winter):11-13.

Heiri, O., Lotter, A.F., and Lemcke, G. 2001. Loss on ignition as a method for estimating organic and carbonate content in sediments: Reproducibility and comparability of results. Journal of Paleolimnology 25(1):101 - 110. http://dx.doi.org/10.1023/A:1008119611481
Hood, G.A., Bayley, S.E., and Olson, W. 2007. Effects of prescribed fire on habitat of beaver (Castor canadensis) in Elk Island National Park, Canada. Forest Ecology and Management 239(1-3):200-209.

http://dx.doi.org/10.1016/j.foreco.2006.12.005

Hugueney, M., and Escuillié, F. 1995. K-strategy and adaptive specialization in Steneofiber from Montaigu-le-Blin (dept. Allier, France; Lower Miocene, MN 2a, \pm 23 Ma): First evidence of fossil life-history strategies in castorid rodents. Palaeogeography, Palaeoclimatology, Palaeoecology 113(2-4): $217-225$. http://dx.doi.org/10.1016/0031-0182(95)00050-V

Hulbert, R.C., Jr., and Harington, C.R. 1999. An early Pliocene hipparionine horse from the Canadian Arctic. Palaeontology 42(6):1017-1025.

Hutchison, J.H., and Harington, C.R. 2002. A peculiar new fossil shrew (Lipotyphla, Soricidae) from the High Arctic of Canada. Canadian Journal of Earth Sciences 39(4):439-443. http://dx.doi.org/10.1139/e01-078

Jones, M.C., and Yu, Z. 2010. Rapid deglacial and early Holocene expansion of peatlands in Alaska. Proceedings of the National Academy of Sciences of the United States of America 107(16):7347-7352. http://dx.doi.org/10.1073/pnas.0911387107

Keddy, P.A. 2010. Wetland ecology: Principles and conservation, 2nd ed. Cambridge: Cambridge University Press. 497 p. http://dx.doi.org/10.1017/CBO9780511778179

Kelts, K., and Hsü, K.J. 1978. Freshwater carbonate sedimentation. In: Lerman, A., ed. Lakes: Chemistry, geology, physics. New York: Springer-Verlag. 295-324.

Kooijman, A.M., and Paulissen, M.P.C.P. 2006. Higher acidification rates in fens with phosphorus enrichment. Applied Vegetation Science 9(2):205-212. http://dx.doi.org/10.1111/j.1654-109x.2006.tb00669.x

Lange-Bertalot, H., Bąk, M., Witkowski, A., and Tagliaventi, N. 2011. Diatoms of the European inland waters and comparable habitats, Eunotia and some related genera. In: Lange-Bertalot, H., ed. Diatoms of Europe, Vol. 6. Koenigstein, Germany: Koeltz Scientific Books.

Lavoie, I., Hamilton, P.B., Campeau, S., Grenier, M., and Dillon, P.J. 2008. Guide d'identification des Diatomées des rivières de l'est du Canada. Québec: Press de l'Université du Québec. $241 \mathrm{p}$.

Lisiecki, L.E., and Raymo, M.E. 2007. Plio-Pleistocene climate evolution: Trends and transitions in glacial cycle dynamics. Quaternary Science Reviews 26(1-2):56-69.

http://dx.doi.org/10.1016/j.quascirev.2006.09.005

Mäkilä, M., and Moisanen, M. 2007. Holocene lateral expansion and carbon accumulation of Luovuoma, a northern fen in Finnish Lapland. BOREAS 36(2):198-210. http://dx.doi.org/10.1111/j.1502-3885.2007.tb01192.x

Mäkilä, M., Saarnisto, M., and Kankainen, T. 2001. Aapa mires as a carbon sink and source during the Holocene. Journal of Ecology 89(4):589-599. http://dx.doi.org/10.1046/j.0022-0477.2001.00586.x 
Marincovich, L., Jr., and Zinsmeister, W.J. 1991. The first Tertiary (Paleocene) marine mollusks from the Eureka Sound Group, Ellesmere Island, Canada. Journal of Paleontology 65(2):242-248.

Matthews, J.V., Jr., and Fyles, J.G. 2000. Late Tertiary plant and arthropod fossils from the high-terrace sediments on Fosheim Peninsula, Ellesmere Island, Nunavut. In: Garneau, M., and Alt, B.T., eds. Environmental response to climate change in the Canadian High Arctic. Geological Survey of Canada Bulletin 529. $295-317$.

http://dx.doi.org/10.4095/211969

Matthews, J.V., Jr., and Ovenden, L.E. 1990. Late Tertiary plant macrofossils from localities in Arctic/Subarctic North America: A review of the data. Arctic 43(4):364-392. http://dx.doi.org/10.14430/arctic1631

Matthews, J.V., Jr., and Telka, A. 1997. Insect fossils from the Yukon. In: Danks, H.V., and Downes, J.A., eds. Insects of the Yukon. Ottawa: Biological Survey of Canada (Terrestrial Arthropods). $911-962$.

McKinstry, M.C., Caffrey, P., and Anderson, S.H. 2001. The importance of beaver to wetland habitats and waterfowl in Wyoming. Journal of the American Water Resources Association 37(6):1571-1577. http://dx.doi.org/10.1111/j.1752-1688.2001.tb03660.x

Miall, A.D. 1986. The Eureka Sound Group (Upper Cretaceous - Oligocene), Canadian Arctic Islands. Bulletin of Canadian Petroleum Geology 34(2):240-270.

Miller, N.G. 1980. Mosses as paleoecological indicators of lateglacial terrestrial environments: Some North American studies. Bulletin of the Torrey Botanical Club 107(3):373-391. http://dx.doi.org/10.2307/2484158

Miller, N.G., and Nestor, P.L. 2006. Paleoecology of a late Pleistocene wetland and associated mastodon remains in the Hudson Valley, southwestern New York State. The Geological Society of America Special Papers 399:291-304.

Mitsch, W.J., Gosselink, J.G., Anderson, C.J., and Zhang, L. 2009. Wetland ecosystems. Hoboken, New Jersey: John Wiley \& Sons, Inc. 295 p.

Murray, A.M., Cumbaa, S.L., Harington, C.R., Smith, G.R., and Rybczynski, N. 2009. Early Pliocene fish remains from Arctic Canada support a pre-Pleistocene dispersal of percids (Teleostei: Perciformes). Canadian Journal of Earth Sciences 46(7):557-570.

http://dx.doi.org/10.1139/E09-037

Naiman, R.J., Melillo, J.M., and Hobbie, J.E. 1986. Ecosystem alteration of boreal forest streams by beaver (Castor canadensis). Ecology 67(5):1254-1269.

http://dx.doi.org/10.2307/1938681

Nowak, R.M. 1999. Walker's mammals of the world, 6th ed. Baltimore, Maryland: The Johns Hopkins University Press. 2 vols.

Odling-Smee, F.J., Laland, K.N., and Feldman, M.W. 2003. Niche construction: The neglected process in evolution. Monographs in Population Biology 37. Princeton, New Jersey: Princeton University Press. 472 p.
Økland, K.A., and Økland, J. 1996. Freshwater sponges (Porifera: Spongillidae) of Norway: Distribution and ecology. Hydrobiologia 330(1):1-30. http://dx.doi.org/10.1007/BF00020819

Ovenden, L.E. 1993. Late Tertiary mosses of Ellesmere Island. Review of Palaeobotany and Palynology 79(1-2):121 - 131. http://dx.doi.org/10.1016/0034-6667(93)90042-S

Pagani, M., Liu, Z., LaRiviere, J., and Ravelo, A.C. 2010. High Earth-system climate sensitivity determined from Pliocene carbon dioxide concentrations. Nature Geoscience 3(1):27-30. http://dx.doi.org/10.1038/ngeo724

Paull, T.M., Hamilton, P.B., Gajewski, K., and LeBlanc, M. 2008. Numerical analysis of small Arctic diatoms (Bacillariophyceae) representing the Staurosira and Staurosirella species complexes. Phycologia 47(2):213-224.

http://dx.doi.org/10.2216/07-17.1

Roulet, N.T., Lafleur, P.M., Richard, P.J.H., Moore, T.R., Humphreys, E.R., and Bubier, J. 2007. Contemporary carbon balance and late Holocene carbon accumulation in a northern peatland. Global Change Biology 13(2):397-411. http://dx.doi.org/10.1111/j.1365-2486.2006.01292.x

Ruez, D.R., Jr. 2009. Framework for stratigraphic analysis of Pliocene fossiliferous deposits at Hagerman Fossil Beds National Monument, Idaho. Rocky Mountain Geology 44(1):33-70. http://dx.doi.org/10.2113/gsrocky.44.1.33

Rybczynski, N. 2007. Castorid phylogenetics: Implications for the evolution of swimming and tree-exploitation in beavers. Journal of Mammalian Evolution 14(1):1-35. http://dx.doi.org/10.1007/s10914-006-9017-3

. 2008. Woodcutting behavior in beavers (Castoridae, Rodentia): Estimating ecological performance in a modern and a fossil taxon. Paleobiology 34(3):389-402.

http://dx.doi.org/10.1666/06085.1

Rybczynski, N., Ross, E.M., Samuels, J.X., and Korth, W.W. 2010. Re-evaluation of Sinocastor (Rodentia: Castoridae) with implications on the origin of modern beavers. PLoS One 5(11): e13990.

http://dx.doi.org/10.1371/journal.pone.0013990

Rybczynski, N., Gosse, J.C., Harington, C.R., Wogelius, R.A., Hidy, A.J., and Buckley, M. 2013. Mid-Pliocene warm-period deposits in the High Arctic yield insight into camel evolution. Nature Communications 4(Article 1550).

http://dx.doi.org/10.1038/ncomms2516

Schokker, J., Cleveringa, P., and Murray, A.S. 2004. Palaeoenvironmental reconstruction and OSL dating of terrestrial Eemian deposits in the southeastern Netherlands. Journal of Quaternary Science 19(2):193-202. http://dx.doi.org/10.1002/jqs. 808

Sharitz, R.R., and Pennings, S.C. 2006. Development of wetland plant communities. In: Batzer, D.P., and Sharitz, R.R., eds. Ecology of freshwater and estuarine wetlands, 1st ed. Berkeley, California: University of California Press. 177-241.

Siver, P.A., and Hamilton, P.B. 2011. Diatoms of North America: The freshwater flora of waterbodies on the Atlantic Coastal Plain. Iconographia Diatomologica 22. 923 p. 
Siver, P.A., and Wolfe, A.P. 2007. Eunotia spp. (Bacillariophyceae) from Middle Eocene lake sediments and comments on the origin of the diatom raphe. Canadian Journal of Botany 85(1):83-90.

http://dx.doi.org/10.1139/b06-143

Siver, P.A., Hamilton, P.B., Stachura-Suchoples, K., and Kociolek, J.P. 2005. Diatoms of North America: The freshwater flora of Cape Cod, Massachusetts, U.S.A. Iconographia Diatomologica 14. $463 \mathrm{p}$.

Tedford, R.H., and Harington, C.R. 2003. An Arctic mammal fauna from the Early Pliocene of North America. Nature 425:388-390. http://dx.doi.org/10.1038/nature01892

Tedford, R.H., Flynn, L.J., Qiu, Z., Opdyke, N.D., and Downs, W.R. 1991. Yushe Basin, China; Paleomagnetically calibrated mammalian biostratigraphic standard from the late Neogene of eastern Asia. Journal of Vertebrate Paleontology 11(4):519-526. http://dx.doi.org/10.1080/02724634.1991.10011420

Tripati, A.K., Roberts, C.D., and Eagle, R.A. 2009. Coupling of $\mathrm{CO}_{2}$ and ice sheet stability over major climate transitions of the last 20 million years. Science 326(5958):1394-1397.

http://dx.doi.org/10.1126/science.1178296

Turetsky, M.R., and St. Louis, V.L. 2006. Disturbance in boreal peatlands. In: Wieder, R.K., and Vitt, D.H., eds. Boreal peatland ecosystems. Berlin: Springer-Verlag. 359-379. http://dx.doi.org/10.1007/978-3-540-31913-9_16

Westbrook, C.J., Cooper, D.J., and Baker, B.W. 2006. Beaver dams and overbank floods influence groundwater-surface water interactions of a Rocky Mountain riparian area. Water Resources Research 42: W06404. http://dx.doi.org/10.1029/2005WR004560
Westbrook, C.J., Cooper, D.J., and Butler, D. 2013. Beaver hydrology and geomorphology. In: Butler, D., and Hupp, C., eds. Treatise on geomorphology, Vol. 12: Ecogeomorphology. San Diego: Elsevier. 293-306.

http://dx.doi.org/10.1016/B978-0-12-374739-6.00337-7

Wilsson, L. 1971. Observations and experiments on the ethology of the European beaver (Castor fiber L.): A study in the development of phylogenetically adapted behaviour in a highly specialized mammal. Viltrevy, Swedish Wildlife 8(3):115-266.

Wolfe, A.P. 2000. A 6500-year diatom record from southwestern Fosheim Peninsula, Ellesmere Island, Nunavut. In: Garneau, M., and Alt, B.T., eds. Environmental response to climate change in the Canadian High Arctic. Geological Survey of Canada Bulletin 529. 249-256.

$\mathrm{Yu}, \mathrm{Z}$. 2006. Holocene carbon accumulation of fen peatlands in boreal western Canada: A complex ecosystem response to climate variation and disturbance. Ecosystems 9(8):1278-1288. http://dx.doi.org/10.1007/s10021-006-0174-2

Yu, Z., Vitt, D.H., Campbell, I.D., and Apps, M.J. 2003. Understanding Holocene peat accumulation pattern of continental fens in western Canada. Canadian Journal of Botany 81(3):267-282. http://dx.doi.org/10.1139/b03-016

Yu, Z., Beilman, D.W., and Jones, MC. 2009. Sensitivity of northern peatlands to Holocene climate change. In: Baird, A., Belyea, L., Comas, X., Reeve, A., and Slater, L., eds. Carbon cycling in northern peatlands. Geophysical Monograph Series 184. 55-69.

Zakrzewski, R.J., and Harington, C.R. 2001. Unusual Pliocene rodent from the Canadian Arctic Islands. Journal of Vertebrate Paleontology 21(3, Suppl.):116A-117A. 